\title{
Kentsel Mekân Üretiminde Belleğin Başkalaşımı: Bomonti Örneği
}

\author{
Tuğçe Gürleyen ${ }^{1}$ \\ ORCID: 0000-0001-6091-8524
}

\author{
Mehmet Ocakç12 \\ ORCID: 0000-0002-2987-1680
}

Öz

Büyük ölçekli kentsel dönüşüm projeleri öncülüğünde hızla üretilen postmodern mekân üretimi, Bomonti Semti'nin bir taraftan tektipleşmesine ve standartlaşmasına, diğger taraftan melezleşmesine tanıklı etmektedir. Yerel kültürün ve kolektif belleğin göz ardı edildiği, bulanılaştığı ve manipüle edilmeye başladığı bu süreçte, gelenekler ve davranış biçimleri birbirine benzer hale gelerek yeniden icat edilmektedir. Metruk sanayi yapılarının sanat galerilerine, butik dükkânlara, kafelere, otellere ve ofis alanlarnna dönüştürülmesi, belirli temalar çerçevesinde kopyalanan ve yeniden inşa edilen melez mekânlara örnek oluşturmaktadır. Dolaşım, tüketim ve iletişim odakl gelişmeleri öne çıkaran ve geleneksel olandan farklılaşan bu alanlar, kısa ömürlü, anlık görüntülerin ve geçiciliklerin yaşandığ 1 ve yer olarak görülmeyen oluşumlara dönüşmektedir. Dolayısıyla, Bomonti'de yaşanan belleğin başkalaşımı, çok boyutlu ve karmaşık mekânsal dönüşümlerin yanı sıra melezleşmenin ve tektipleşmenin bir ürünüdür. Bu çalışma, farkl yaşamların çoğul pratiklerini ve kolektif belleğin örgütlenme biçimlerini planlama ve tasartm sürecine aktarabilmenin önemini vurgulamaktadır. Geçmişten günümüze süregelen kentsel deneyimler ortaklığında toplumsal olarak inşa edilmiş yaşam alışkanlıklarını, mekân ve ortak hafiza ekseninde keşfetmeyi amaçlamaktadır.

Anahtar Kelimeler: Belleğin başkalaşımı, manipülasyon, tektipleşme, melezleşme, Bomonti

\footnotetext{
${ }^{1}$ Doktora Öğrencisi, İTÜ, E-mail: tugcegurleyen@gmail.com

2 Prof. Dr., İTÜ, E-mail: mocakci@itu.edu.tr

id ealkent @ Kent Araştırmaları Dergisi (Journal of Urban Studies) 


\title{
Metamorphosis of Memory in the Production of Urban Space: The Example of Bomonti
}

\author{
Tuğçe Gürleyen ${ }^{3}$ \\ ORCID: 0000-0001-6091-8524
}

\author{
Mehmet Ocakç1 ${ }^{4}$ \\ ORCID: 0000-0002-2987-1680
}

\begin{abstract}
The rapid production of postmodern space produced under the leadership of large-scale urban transformation projects not only witnesses to the homogenisation and standardization but also to the hybridization of the Bomonti District. In this process, where local culture and collective memory are ignored, blurred and begin to be manipulated; traditions and patterns of behaviour are reinvented by becoming similar. Abandoned buildings and industrial warehouses converted into art galleries, expensive shops, cafes, hotels, residential and office spaces are an example of hybrid spaces where copies of historical sites are built or developed based on specific themes. These areas, which stand out as places of circulation, consumption and communication and differ from traditional ones, turn into placeless formations where short-lived, instant images and impermanence are experienced. Therefore, the metamorphosis of memory experienced in Bomonti is the outcome of the hybridization as well as the multi-dimensional and complex spatial transformations. This study emphasizes the importance of transferring the plural practices of different lifetimes and the organizational forms of collective memory to the planning and design process. It aims to explore socially constructed habits of life with the collaboration of urban experiences from past to present in the context of space and shared memory.
\end{abstract}

Keywords: Metamorphosis of memory, manipulation, homogenisation, hybridization, Bomonti

\footnotetext{
${ }^{3}$ PhD Student, ITU,E-mail: tugcegurleyen@gmail.com

${ }^{4}$ Prof. Dr., ITU, E-mail: mocakci@itu.edu.tr

idealkent @ Kent Araştırmaları Dergisi (Journal of Urban Studies) 


\section{Giriş}

Sosyal gruplar (bellek tüketicileri), profesyoneller ve karar vericiler (bellek üreticileri) arasındaki meşruiyet çatışmaları, kentlerde politik bir iç mantığın olduğunu göstermektedir (Kansteiner, 2002; Weber, 2009). Kentsel mekânın meşrulaştırma biçimleri, siyasi otoritenin tutumları ile inananlar/yönetilenler arasındaki dügü̈m üzerine kurulmaktadır. Düğümün yarattığı çatlakta hafızanın kaydını tutan politik güç, kolektif belleğin çarpıtılma dinamiklerini ortaya koymakta ve kurucu geçmişin belirlenmesinde etkin rol üstlenmektedir (De Certeau, 1990; Ricoeur, 2004). Hâkim ideolojilerin geçmişi harekete geçirip kendi amaçları doğrultusunda kullandığı düşünüldüğünde, bellek politikası bugünün kentleşme politikası haline gelmektedir. Kentsel mekân üretiminin yasal araçlarla desteklenmesine rağmen, planlama, uygulama ve denetim süreçlerinin kolektif bağlamdan kopuk olması ve yönetsel, zihinsel ve duyumsal açıdan kopukluklar yaşanması, kurucu geçmişin yeniden üretilmesine ve mekânların tektipleşmesine neden olmaktadır.

Öte yandan, ideolojik söylemler çerçevesinde belleği etkisizleştiren kentleşme siyasaları ve mekânsal pratikleri, öznel ve kolektif deneyimlere bağlı olarak gelişen toplumsal etkileşimleri, yerin anlamın, kimliğini ve duygusunu göz ard1 etmektedir. Kolektif belleğin kentsel sistemdeki görünürlüğünü ve sürekliliğini kesintiye uğratarak hafızası olmayan yerlere dönüştürmektedir. Bu nedenlerden dolayı, geçmişin meşruluğu (geriye dönük) ve gelecek bilincinin topluma kazandırılması (ileriye dönük) mümkün olamamaktadır. Bu bakımdan, ortak değerleri, geçmişin temsillerini ve kolektif deneyimleri bir araya getirmeyi amaçlayan kentsel bellek stratejilerine ve taktiklerine ihtiyaç duyulmaktadır.

$\mathrm{Bu}$ çalışma, geçmişten günümüze süregelen kentsel deneyimler ortakl1ğında toplumsal olarak inşa edilmiş yaşam alışkanlıklarını, mekân ve ortak hafıza ekseninde keşfetmeyi amaçlamaktadır. Mekânın toplumsal üretimini, geçmişin ve bugünün bellek izleri ile anlamaya çalışmaktadır. Farklı yaşamların çoğul pratiklerini ve kolektif belleğin örgütlenme biçimlerini planlama ve tasarım sürecine aktarabilmenin önemini vurgulamaktadır. Çalışma kapsamında, niceliksel ve niteliksel araştırma biçimi olan görsel etnografi yönteminden yararlanılmıştır. Tarihsel katmanlar üzerinden yapılan kentsel bellek okuması, kişisel veya resmi arşivlerde bulunan eski haritalara, gravürlere, fotoğraflara, çizimlere, kartpostallara ve metinlere dayanmaktadır. Kırılganlaşan veya kesin- 
tiye uğrayan, manipüle edilen, yeniden üretilen ve süregelen mekânsal ve toplumsal izler, bellek teorileri çerçevesinde karşılaştırmalı olarak değerlendirilmiştir.

\section{Kolektif Bellek Bağlamında Kentsel Mekân Üretimi}

İnsanların bilinçli faaliyet alanı olan bellek, kolektif deneyimlerin korunması, çağrılması ve işlenmesinde etkin rol oynamaktadır. İnsanları ortak bir kimlik altında birbirine bağlayan, grup etkileşimleri ve hatırlama eylemleri ile canlı tutulan kolektif bir varliktır (Lewicka, 2008; Kansteiner, 2002; Ricoeur, 2004; Wertsch, 2002; Winter, 1999). Dolayısıyla, bireysel deneyimlerin hatırlandığı bir düşünce sisteminin yanı sıra toplumsalı oluşturan, geçmişin yeniden inşa edilme sürecinde paylaşılan ve ortaklaşılan eylemlerdir (Misztal, 2003). Kolektif belleği biçimlendiren toplumsal olarak kazanılmış bu çerçeve, mekânların toplumsal olarak üretilmesi gerektiği görüşüne dayanmaktadır (Lefebvre, 1993).

Tablo 1. Bireysel ve kolektif bellek bağlamında kentsel mekân üretimi (Assmann, 2001; Connerton, 2009; Crane, 1997; Crinson, 2005; Halbwachs, 1990; Halbwachs, 1992; Hobsbawm ve Ranger, 2012; Hutton, 1993; Misztal, 2003; Nora, 1989 çalışmalarına referansla yazar tarafından üretilmiştir.)

\begin{tabular}{|c|c|}
\hline \multirow{4}{*}{ Bireysel Bellek } & Gündelik deneyimler \\
\hline & Gündelik olanın sıradanlığı \\
\hline & Yineleyici tekrar dizileri \\
\hline & Sembolik biçimler \\
\hline \multirow{6}{*}{ Kolektif Bellek } & Geçmişin temsili \\
\hline & Geçmişin yeniden inşası \\
\hline & $\begin{array}{l}\text { İnançlar ve gelenekler kümesi } \\
\text { Geleneğin icadı }\end{array}$ \\
\hline & Grubun benzersizliği \\
\hline & $\begin{array}{l}\text { Ortak kimlik altında hatırlama eylemleri } \\
\text { Paylaşılan ve ortaklaşlan eylemler }\end{array}$ \\
\hline & Mekânın toplumsal üretimi \\
\hline
\end{tabular}

Kolektif bellek, mekânsal ortamda tezahür eden sembolik biçimler, sosyal gruplar tarafindan nesiller boyunca paylaşılan deneyimler, inançlar ve gelenekler kümesidir (Halbwachs, 1992). Assmann'ın (2001) geçmiş ve şimdiki zaman arasında bağlayıcı olarak adlandırdığı bu yapı, geçmişin bir temsili olarak görülse de geleneklerden törensel eylemlere, bedensel pratiklere ve yerlere kadar farklı şekillerde aktarılmaktadır (Connerton, 2009). Kolektif belleğin ayırt edici özelliği, gündelik olanın sıradanlığı içerisinde oluşan yineleyici tekrar dizilerine (Connerton, 2009; Hutton, 1993), grubun benzersizliğine (kimliği) ve 
geçmişin süreklilik duygusuna (Halbwachs, 1990) bağlıdır. Bir diğer ifadeyle, kuşaklar arasında paylaşılan gündelik deneyimlerin, geçmiş hatıraların ve kimliklerin toplumsal bir algiya dönüşmesi ile ilgilidir (Crane, 1997; Crinson, 2005). Kolektif belleğin köktenci görüşü, geleneğin icadını (Hobsbawm ve Ranger, 2012) ve hayali bir topluluğun inşasını (Nora, 1989) mümkün kılmaktadır.

Tablo 2. Kentsel kolektif belleğin oluşumuna etki eden bileşenler (Alba, 2012; Amin ve Thrift, 2002; Burke, 2004; Connerton, 2009; Durkheim, 2013; Halbwachs, 1992; Hutton, 1993; Kansteiner, 2002; Nora, 1989; Zhu, 2004 çalışmalarına referansla yazar tarafından üretilmiştir.)

\begin{tabular}{lll}
\hline \multicolumn{2}{l}{ Kentsel kolektif bellek bileşenleri } & \\
\hline Bellek üreticileri & Bellek tüketicileri & $\begin{array}{l}\text { Entelektüel ve kültürel gelenek- } \\
\text { ler }\end{array}$ \\
\hline Dişsal bileşen & İçsel bileşen & Geçmişin temsili \\
\hline mekânsal işaretler & bedensel eylemler & $\begin{array}{l}\text { hatıralar } \\
\text { gelenekler }\end{array}$ \\
tarihsel katmanlar & törenler ve ritüeller & sözlü iletişim \\
& somut olmayan kaynaklar & metinler \\
& kathlımc eylemler & \\
& karşlaşma anları & \\
& gündelik deneyimler & \\
& tekrarlar &
\end{tabular}

Geçmişin tüm temsillerini çerçeveleyen entelektüel ve kültürel gelenekler, bu gelenekleri seçici bir şekilde manipüle eden bellek üreticileri (dışsal bileşen) ve kendi çıkarlarına göre kullanan, göz ardı eden veya dönüştüren bellek tüketicileri (içsel bileşen) kentsel kolektif belleğin oluşumuna etki eden bileşenlerdir (Kansteiner, 2002). Sözlü gelenekler, metinler, bedensel eylemler, törenler ve ritüeller, somut olmayan kaynaklar (Connerton, 2009; Burke, 2004; Durkheim, 2013; Halbwachs, 1992; Nora, 1989), katilımc eylemler ve hatralar (Zhu, 2004) ve karşılaşma anları (Amin ve Thrift, 2002) kentsel kolektif belleğin içsel bileşenleridir. Bellek tüketicileri, geleneklere katkıda bulunan ve gelecek nesillere aktarılmasına olanak sağlayan geçmiş nesillerin grup üyeleri olarak yorumlanabilir. Mekânsal işaretler (Halbwachs, 1992) ve tarihsel katmanlar (Alba, 2012) belleğin dışsal bileşenlerini oluşturmaktadır. Bellek üreticileri tarafından kolektif belleğin seçici olarak benimsenmesi veya manipülasyonu dişsal bileşenlere bağlı olarak gelişmektedir.

\section{Araştırma Yönteminin Kapsamı ve Kuramsal Çerçevesi}

Bu çalışma, mekânın toplumsal üretimini geçmişin ve bugünün bellek izleri ile anlamaya çalışırken, Bomonti'nin kentsel bellek sistemini "kırılma, kopma, manipüle edilme, süreklilik ve birleşme" bağlamında incelemektedir. Bu doğ- 
rultuda takip edilen görsel ve etnografik analiz yöntemleri, mekânsal ve toplumsal olanın bağdaşık ve koparılamaz ilişkisini görgül sonuçlarla desteklemektedir.

Etnografik araştırmalar, nitel düşünceye dayalı sistematik bilgi üretmede yaygin olarak kullanılan yöntemlerden biridir. Vaka incelemesi, gözlem, arşiv araştırması, haritalama, günlük tutma, yaşam öyküleri gibi oldukça çeşitli teknikler sunmaktadır. Arşiv araştırması (yazılı ve görsel kaynaklar, eski haritalar, planlar, uydu görüntüleri, diyagramlar, eskiz çizimleri ve fotoğraflar) yoluyla elde edilen veriler, mekânın biçimlenmesi ve gündelik yaşam deneyimleri hakkında bilgi sunmaktadır (Blomberg, 1993). Kentsel mekânın zamansal ve toplumsal çok katmanlı yapısını ortaya çıkarmaktadır. Bunların yanı sıra, bellek üreticilerinin karar mekanizmalarını ve gelecek öngörülerini anlamak için önemli bir araç olarak kullanılmaktadır (Burke, 2004).

Araştırmanın veri toplama aşamasında, görsel etnografi yöntemi kullanılmıştır. Bu yöntem, fotoğraf, çizim ve haritalar aracilığıyla sosyo-mekânsal verilerin toplanması sürecidir. Niceliksel ve niteliksel araştırma biçimi olarak görsel etnografi, şehircilik çalışmalarında önem kazanmaktadır (Stone, 2013). Kentsel mekânda toplumsal yaşama dair açklayıcı anlatılar üretmektedir (O'Reilley, 2009). Toplumsal mekânın dinamizmi ve akışkanlığı içerisinde belleğin ve anlamın oluşumsal izlerinin anlaşılmasına olanak sağlamaktadır (Till, 2005).

Bomonti Semti'nde belleğin başkalaşım süreci, görsel etnografi yönteminden yararlanılarak, kişisel veya resmi arşivlerde bulunan eski haritalar, gravürler, fotoğraflar, çizimler, kartpostallar ve metinler aracilığıla tarihsel katmanlar üzerinden incelenmiştir. Kırılganlaşan veya kesintiye uğrayan, manipüle edilen, yeniden üretilen ve süregelen mekânsal ve toplumsal izler, bellek teorileri çerçevesinde karşılaştırmalı olarak değerlendirilmiştir.

Tablo 3. Belleğin başkalaşım süreci (Gürleyen, 2018)

\begin{tabular}{|c|c|c|c|}
\hline \multicolumn{4}{|l|}{ Belleğin başkalaşımı } \\
\hline Bellek üreticileri & & Bellek tüketicileri & \\
\hline $\begin{array}{l}\text { Belleğin kırılganlığı ve } \\
\text { kesintiye uğraması }\end{array}$ & Belleğin manipülasyonu & $\begin{array}{l}\text { Belleğin yeniden } \\
\text { üretimi }\end{array}$ & Belleğin sürekliliği \\
\hline $\begin{array}{l}\text { mekânsal hafiza izlerinin } \\
\text { kentsel sistemden kopa- } \\
\text { rılması } \\
\text { düşünsel ve tasarımsal } \\
\text { araçlarının } \\
\text { yitirilmesi }\end{array}$ & $\begin{array}{l}\text { ideolojik unutturma biçimleri } \\
\text { yeni ama orijinal olmayan } \\
\text { hafıza } \\
\text { yersizleşme, tektipleşme } \\
\text { ve uyarlama anlamlar } \\
\text { geleneklerin seçici olarak mani- } \\
\text { püle edilmesi } \\
\text { geleneğin yeniden icadı } \\
\text { bellekte yaşanan çarpıklıklar }\end{array}$ & $\begin{array}{l}\text { belleği kendi çkarları } \\
\text { doğrultusunda kul- } \\
\text { lanma, göz ardı etme ve } \\
\text { dönüştürme }\end{array}$ & $\begin{array}{l}\text { kentsel sistemle bütünle- } \\
\text { şen yeni mekânsal olu- } \\
\text { şumlar } \\
\text { yere özgü şekillenen gün- } \\
\text { delik yaşam pratikleri } \\
\text { süregelen toplumsal ilişki- } \\
\text { ler }\end{array}$ \\
\hline
\end{tabular}


Kentsel mekân üretiminde hatıraları, deneyimleri ve gelenekleri anlamlı çağdaş formlara dönüştüren yorumsal araçların yitirilmesi, bellek üreticileri tarafindan alınan kararlarının etkisiyle mekânsal bütünlügün ve kültürel birikimlerin kentsel sistemden koparılması, belleğin kırılganlığı ve kesintiye uğraması çerçevesinde değerlendirilmiştir.

Mekânsal örgütlenmenin yıkım-yapım sürecinde, ideolojik unutturma biçimi olarak ortaya çıkan yeni ama orijinal olmayan hafıza (Postalcy ve ark., 2006), yersizleşme, tektipleşme ve uyarlama anlamlar (Auge, 2008), geleneğin yeniden icad1 (Hobsbawn ve Ranger, 2012), geleneklerin seçici olarak manipüle edilmesi ve bellekte yaşanan çarpıklıklar (Burke, 2004), kurucu nostalji ve melez oluşumlar (Boym, 2009), belleğin manipülasyonu çerçevesinde ele alınmıştir.

Bellek tüketicilerinin hafızayı kendi çıkarları doğrultusunda kullanma, göz ardı etme ve dönüştürme eğilimleri, belleğin yeniden üretilmesi kapsamında ele alınmıştır. Kentsel sistemle bütünleşen yeni mekânsal oluşumlar, gündelik yaşam pratikleri ve süregelen sosyal ilişkiler, belleğin sürekliliği bağlamında incelenmiştir.

\section{Çalışma Alan Sınırı}

Bomonti Semti, büyük ölçekli konut politikalarının etkisi altında kalan, küresel eğilimlerin yaşandığı, tarihsel sürekliliklerin ve kırılganlıkların aynı anda gözlemlendiği bir düzlemde yer almaktadır. Geçmiş hafıza izlerinin belirgin bir şekilde sergilendiği gündelik yaşam pratiklerinin yanı sıra, toplumsal ve mekânsal değişimlerle birlikte kentsel unutkanlığın ve manipülasyonun da baskınlaştı̆̆ görülmektedir. Bu nedenlerden ötürü, Bomonti Semti çalışma alanı olarak seçilmiştir.

Bomonti Semti'nin tam sinırı bilinmemekle beraber Cumhuriyet Mahallesi'nin tamamını ve Merkez Mahallesi'nin bir kısmını içine almaktadır. Bomonti Semti'nin zihinsel sınırlarını belirlemek amaciyla yüz yüze görüşmeler yapılmıştır. Bomonti Semti'nde yapılan 50 görüşmenin \%48'ini mahalleyi ziyaret edenler veya çalışanlar, \%52'sini mahallede ikamet edenler oluşturmaktadır. Katılımclara sorulan, "Bomonti' nin sinurlarını ve zorunlu hareketleriniz dişındaki gündelik yürüme güzergâhınızı harita üzerinde çizebilir misiniz?" sorularına verilen yanıtlar çalışma alan sınırını oluşturmuştur. 


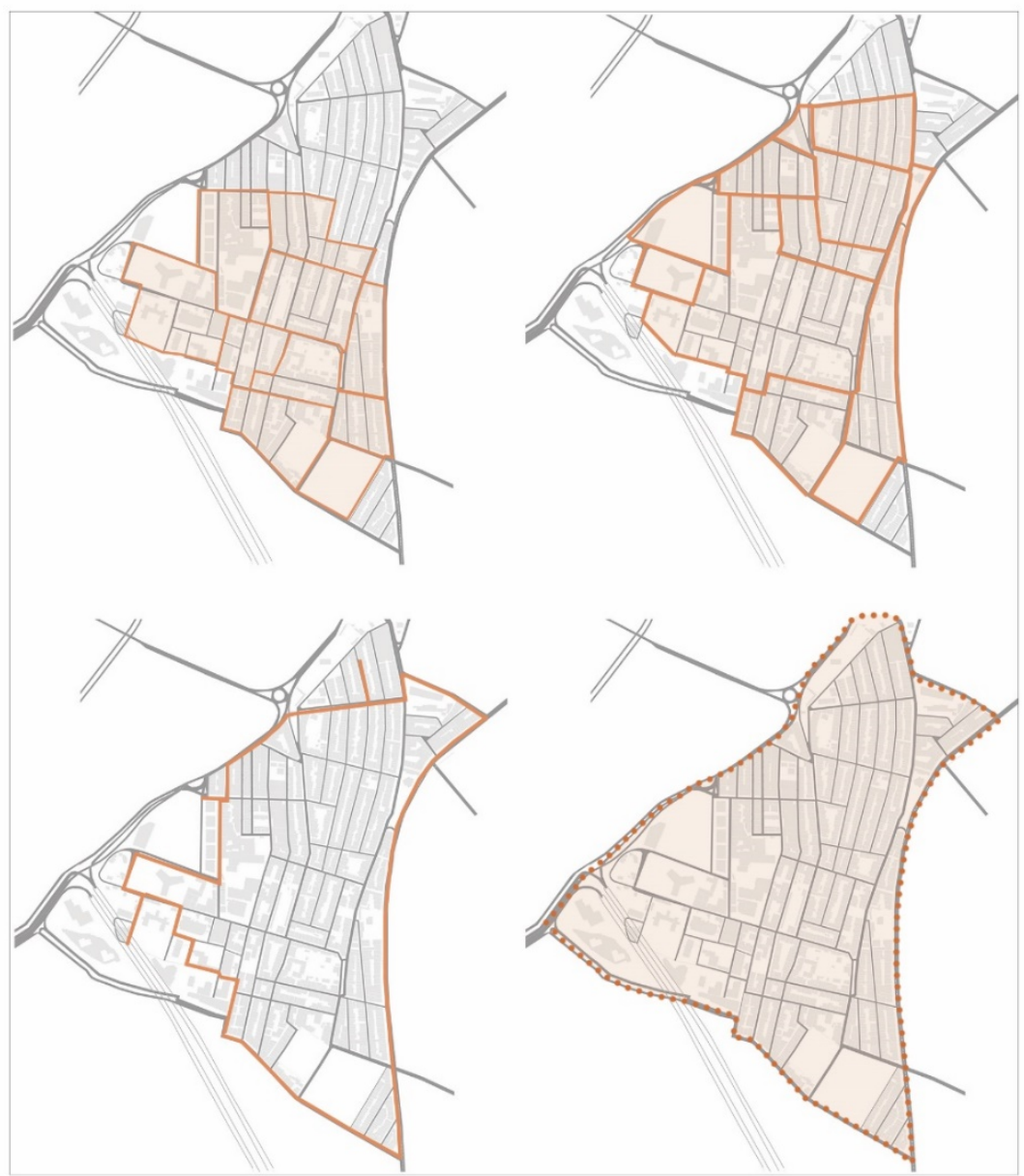

Şekil 1. Bomonti Semti'ni ziyaret eden katılımclar tarafından tanımlanan mahalle sınırı; Bomonti Semti'nde yaşayan katılımclar tarafından tanımlanan mahalle sınırı; Bomonti Semti'nin gündelik güzergâhları; çalışma alan sınırı (Kişisel Çalışma)

Bomonti Semti'ni ziyaret eden katılımcların gözünden mahalle sınırı, Ergenekon Caddesi'nden başlayarak Halaskargazi Caddesi üzerinde konumlanan Bulgar Kilisesi'ni içine alacak şekilde devam eden, batı yakasında Duçi Sokak ve Yeni Yol Sokağa kadar uzanan bir bölgeyi kapsamaktadır. Bomonti Semti'ni yaşayarak deneyimleyen insanların tarif ettikleri sınır, Ergenekon ve Halaskargazi Caddesi'nden Hasat Sokağı'na kadar uzanarak Çifte Cevizler Caddesi'nin bitimine kadar devam etmektedir. Mahalle sınırı, dışarıdan gelen kullanıcilardan farklı olarak; Huzur ve Harzemşah Sokağın kuzey kısmını ve Şişli Cami’yi içine almaktadır. Ayrıca, eskiden bostan, sebze bahçesi ve tarımsal pazar olarak 
kullanılan Bomonti Arkası Sokak ve Çifte Cevizler Caddesi arasında kalan bölge de sınırlara dâhil edilmiştir. Bomonti Semti kullanıcıları tarafından tarif edilen mahalle sinırları ile gündelik güzergâhların sentezlenmesi sonucunda çalışma alan sınırı ortaya çıkmıştır.

\section{Bomonti Semti'nin Tarihsel Katmanları üzerinden Belleğin Başkalaşımı}

\section{0 öncesi dönem}

1870 yılında Beyoğlu'nun büyük bir kısmını ortadan kaldıran yangın felaketi ve Tanzimat'la birlikte yabancların ve azınlıkların mülk edinmelerini kolaylaştıran gelişmelerin ardından, kentin gelişimi Şişli'ye doğru uzanmıştır. 1885 tarihli Hueber Haritası'nda, Bomonti Semti'nin ve Bira Fabrikası'nun ilk oluşum izlerine rastlanmaktadır. Bomonti Semti'nin kentin kenarında gelişmeye başlaması, sanayi tesislerinin yer seçim kararlarından kaynaklıdır (Tümertekin, 1972). 1900 İstanbul Bölge Planı'nda, Bomonti Semti'nin "bakla tarlası" olarak bilinen bir arazi üzerinde ve küçük ölçekli fabrikalara yakın konumda geliştiği görülmektedir. 1910 yılından itibaren, batı kültürünü benimseyen aydınların ve seçkinlerin gereksinmeleri sonucunda, Halaskargazi ve Sıra Cevizler Caddesi üzerinde konaklar ve lüks apartmanlar oluşmaya başlamiştır.

1918 Necip Haritası'nda, Bomonti Bira Fabrikası yakın çevresinde bostan, sebze bahçesi ve yeşil alanların olduğu görülmektedir. 1922 İstanbul Şehir Haritası'nda, fabrikaların kurulması ve ulaşım bağlantılarının güçlenmesiyle birlikte bahçelerin ve bostanların etrafında gecekondu yerleşimleri oluşmaya başlamıştır. 1924 Pervititch ve 1926 Rumeli Ciheti Haritası'nda, Bomonti Bira Fabrikası'nın inşa edildiği Cevizli Nehri'nin her iki tarafında da küçük sanayi tesisleri, sebze bahçeleri ve tarım alanlarının yer aldığı görülmektedir. Bira Fabrikası ve sanayi ürünleri, bölgenin biçimlenmesinde etkin rol oynarken, aynı zamanda mahallenin çehresini değiştirmiştir. 1930 yıllarında fabrikanın yanına kurulan Bomonti Bahçesi ve sosyal ürünleri, gündelik hayatın biçimlenmesinde önemli bir rol üstlenmiştir. Bunun yanı sıra, farklı kültürlerin bir arada yaşadığı ve semt kültürünün temellerinin atıldığı bir yer niteliği kazanmıştır. 

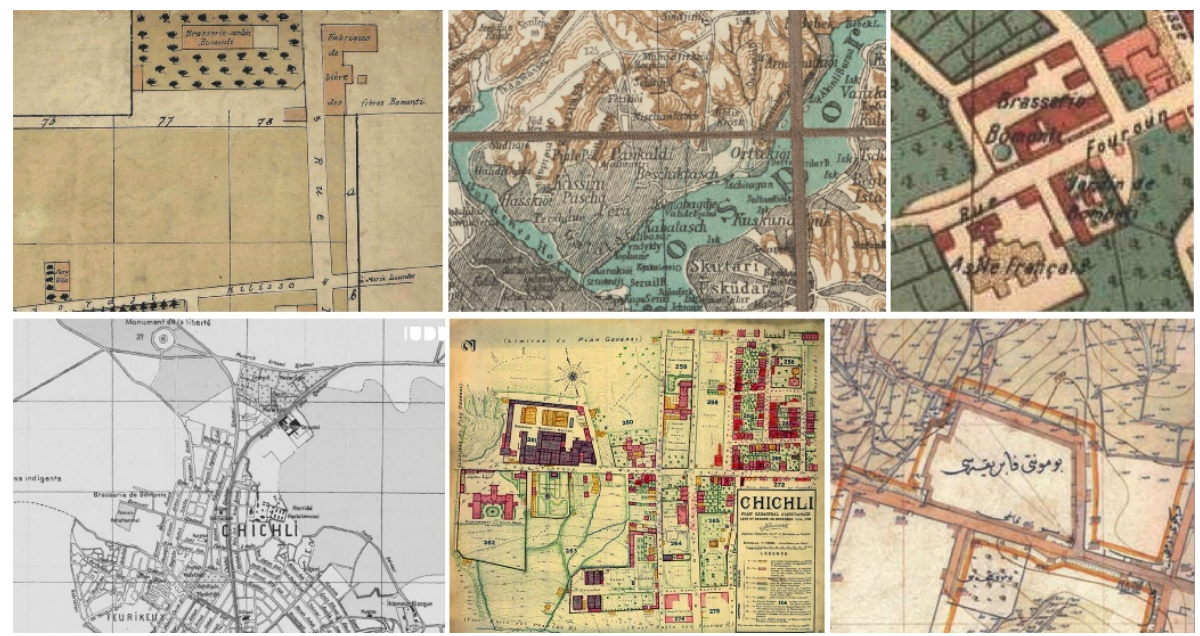

Şekil 2. 1885 Hueber Haritası, 1900 İstanbul Bölge Planı, 1918 Necip Bey Haritası, 1922 İstanbul Şehir Haritası, 1924 Pervititch Haritası, 1926 Rumeli Ciheti Haritası: Bomonti'nin oluşum izleri (Kaynak: İstanbul Atatürk Kitaplığı Eski Haritalar Koleksiyonu; İTÜ Çevre ve Şehircilik Uygulama-Araştırma Merkezi)
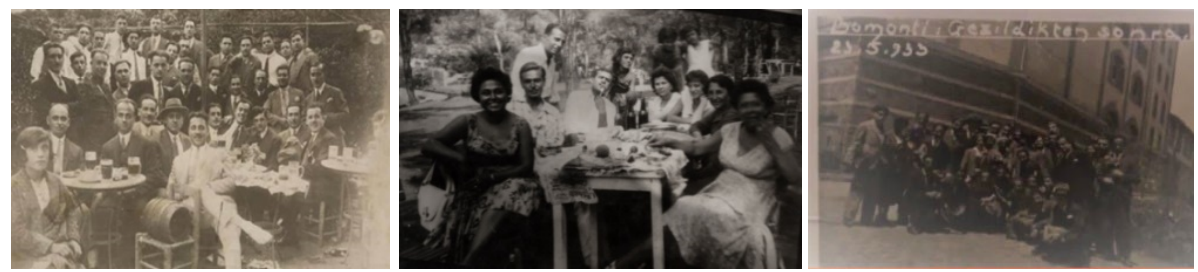

Şekil 3. 1940 öncesi Bomonti'nin Bira Bahçesi'nde ve sokaklarında gündelik yaşamın izleri (Zat, 1994)

Bomonti Bira Bahçesi, sosyal yardımlaşma etkinliklerine, sanatçıların katıldığı etkileşimli buluşmalara, iş adamlarının davet edildiği toplantılara, çocuklardan yaşlılara kadar farklı yaş grubundan insanların biraraya geldiği kutlamalara tanıklık etmiştir. Sosyalleşme, etkileşme, toplanma, karşılaşma, buluşma, dinlenme ve sohbet etme alanları olarak kolektif deneyimlerin çeşitlenmesine imkân sağlamıştır (Ögü̈t, 2010). Yemek yemek, içki içmek ve sohbet etmek gibi basit eylemleri gerçekleştirmek için topluluğun bir araya gelmesi, doğal ve mekânsal düzenin anlam kazanmasına yardımcı olmuştur (Lefebvre, 2012). Bomonti Bira Bahçesi'nde kitap okuma, şarkı söyleme, şiir okuma, dans etme, politik, kültürel ve sanatsal tartışma faaliyetlerini sürdürme eğilimleri, yeni ve geleneksel işlevleri bir araya getirmiş, entelektüel ve kültürel geleneklerin aktarımında etkili ve kolektif yönü güçlü unsurlar olarak belirginleşmiştir. 


\section{0-1950 dönemi}

1940'ların başlarında, sanayi tesislerinin kurulmasında rol oynayan Musevi, Rum ve Ermeni azınlıklarının çalışma, yaşama ve eğlenme alışkanlıklarını beraber sürdürme eğilimleri, fabrika ve konut yer seçim kararlarını etkilemiştir (Doldur, 2009). Konut ve çalışma alanlarının birbirine yakın olması ve diğer kentsel kullanımlarla kurduğu ilişki, Bomonti Semti'nde homojen bir mekânsal dağılımın olduğunu göstermektedir (Tümertekin, 1972).

Çalışma alanlarının konut etrafında düzenlenmesi, sanayi tesislerinde çalışan işçilerin büyük çoğunluğunun yakın meskûn alanlarda yaşaması ve üretim alanlarının yaşamla iç içe olması, gündelik yaşam öğelerinin birbirlerini kapsayan diyalektik ilişkilerine imkân sağlamaktadır. Çeşitli dinsel, etnik ve ekonomik farklılaşmalara rağmen hoşgörü ortamınn benimsendiği görülmektedir. Bunların yanı sıra, 1947 yılında Bomonti Bira Fabrikası'nda ilk işçi sendikasının kurulması ile birlikte, örgütlenme ve kolektif hareket etme kültürünün kurumsallaştı̆̆ anlaşılmaktadır. Bomonti Semti, halkın egemenliğinin ve demokrasinin bütünleştiği bir yer haline gelmiştir (Akın, 2007).

1940-1950 döneminde Bomonti Semti, kolektif ihtiyaçlara göre ortaya çıkan kendiliğinden oluşumlara imkân sağlamaktadır. Kolektif ve rastlantısal gelişen mekânsal organizasyonun yanı sıra dinsel bayramlar, ayinler, törenler, kutlamalar ve ortaklaşa eylemler, kentsel belleğin düğüm noktalarını oluş̧urmaktadır. Somut olmayan kaynakların yere kök saldığı, entelektüel ve kültürel geleneklerin aktarımında etkili olduğu anlaşılmaktadır. Sokakların kesişim noktaları, bina kenarları, üretim tesisleri ile konut yapıları arasındaki boşluklar, gündelik aktivitelerin sürdürüldüğü mekânlar olarak sosyal yaşamın hareketliliğini içinde barındırmıştır (Öğ̈̈t, 2010).
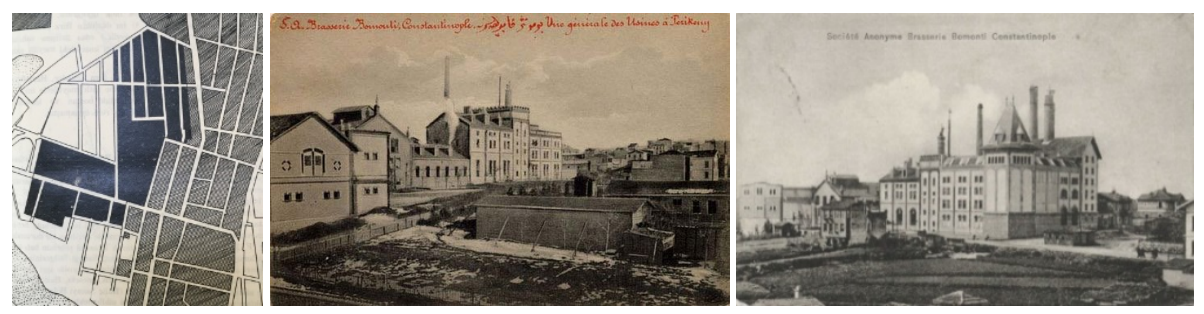

Şekil 4. Bomonti Bira Fabrikası ve yakın çevresinin kendiliğinden gelişen sanayi karakteri (Tümertekin, 1967; İstanbul Atatürk Kitaplığı Nadir Eserler Koleksiyonu) 

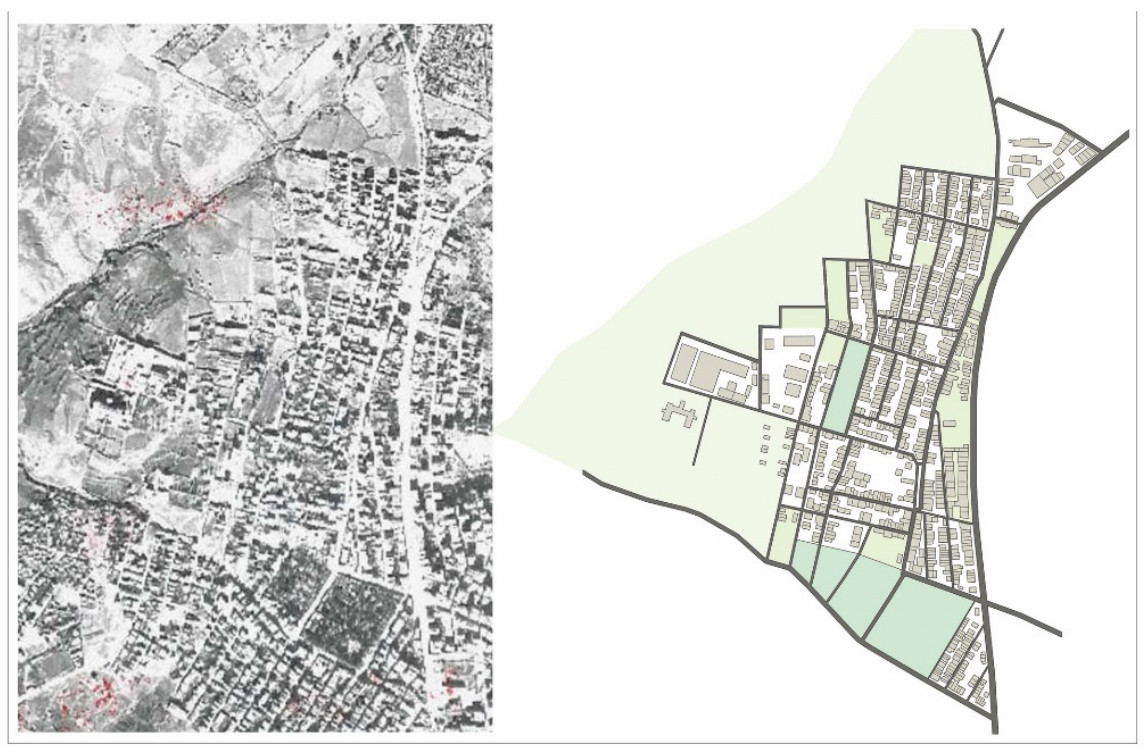

Şekil 5. 1940-1950 dönemi Bomonti Semti'nin mekânsal örüntüsü (İBB Şehir Haritası, Gürleyen; 2018)

Bostanlar, sebze bahçeleri, Bira Bahçesi, dere kenarı ve sokak köşelerinde konumlanan küçük cep pakları yeşil alan sürekliliğinin sağlanmasına yardımcı olmuştur. Açık yeşil alanlarda düzenlenen panayırlar ve kutlamalar, ortak bir kültürü ve yaşantıyı temsil etmiştir. Topluluklar tarafından sürdürülen, sevinç ve ortaklık üzerine kurulu olan bu etkinlikler, doğa ve yerin düzeniyle işbirliği içerisinde anlam kazanmıştır (Lefebvre, 2012).
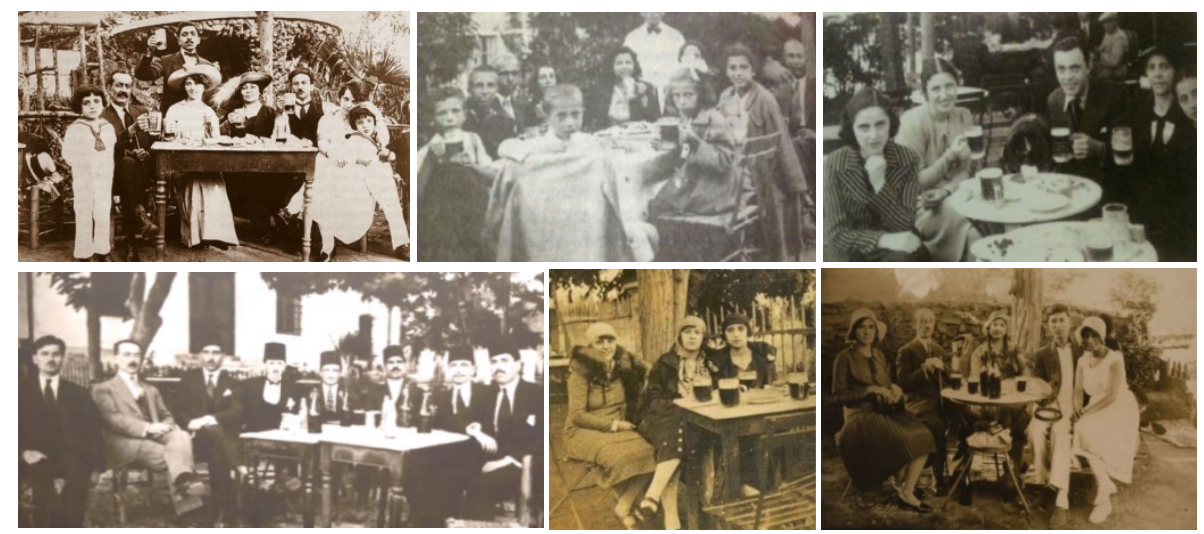

Şekil 6. 1940'larda Bomonti Bira Bahçesi'nde belleğin toplumsal çerçevesi (Sandalc1, 2017) 


\section{0-1970 dönemi}

Beyoğlu Nazım İmar Planı'nda (1954) Bomonti Bira Fabrikası ve yakın çevresi sanayi alanı, Halaskargazi Caddesi ve Siracevizler Caddesi arasında kalan bölge orta yoğunluklu konut alanı, Abide-i Hürriyet Caddesi etrafındaki bölge düşük yoğunluklu konut alanı ve vadinin güneybatı kesimleri yeşil tampon alan olarak gösterilmiştir. Bu dönemde planlama politikalarının etkisiyle, sanayi bölgesi sınırları konut alanlarına kadar genişlemiştir. Böylelikle, Bomonti Semti, üretim kimliğini korumaya ve sürdürmeye devam etmiştir. Bostan ve tarım arazileri üzerinde sanayi tesisleri kurulmaya başlamıştır. Vadinin güney ve batı yakasında geniş bir alana dağınık bir şekilde yayılmaya devam eden gecekondu yerleşimleri, farklı toplulukların ve yeni sosyal dokunun ortaya çıtığını göstermektedir. Bunun yanı sıra, sanayi tesisleri ile modern apartmanların yan yana ve iç içe olduğu görülmektedir (Tümertekin, 1967).

Önceleri boş veya tarım alanlarına inşa edilen apartmanlar, zamanla yeşil alanlar, parklar ve oyun alanlarının yerine geçerek kamusal alanların yitirilmesine neden olmuştur. Bomonti'nin mekânsal ve somut olmayan bileşenleri ile belleğin yeniden biçimlenmesinde yaşanan yetersizlikten ötürü, üretim kimliği ve bahçe kültürü kentsel bellek sisteminden koparılmıştır. Belleği manipüle etme amaciyla uygulanan mekânsal müdahaleler, geçmişin bilinçli yeniden yapılanmasının kritik bir parçası haline gelmeye başlamıştır.

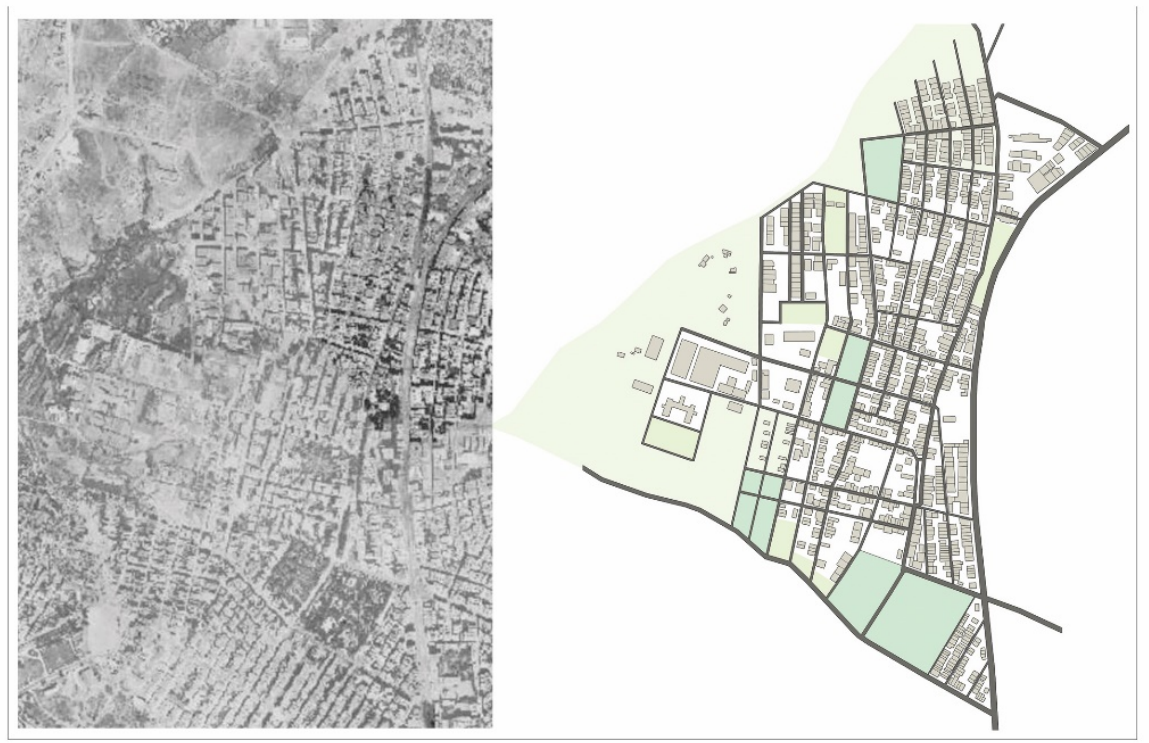

Şekil 7. 1950-1970 dönemi Bomonti Semti'nin mekânsal örüntüsü (İBB Şehir Haritası; Gürleyen, 2018) 
Öte yandan, kentsel mekânlar kamusal niteliğini sürdürerek, farklı kullanıcıların uğrak yeri haline gelmiştir. Toplanma, buluşma, karşılaşma ve etkileşim kurma gibi kolektif eylemlere olanak sağlamıştır.

Bomonti'nin kendine özgü yaşam biçimi ve alışkanlıkları çerçevesinde tekrarlanan gündelik yaşam döngüsü, farklı imgelerin rastlantısal dışavurumlarını ve kendi mekânsal örüntüsünü yaratmıştır. Sembolik mekânsal formlar, kentsel kolektif belleğin önemli bir bileşeni haline gelmiştir. Pazar günleri ailecek yapılan gezintiler ve yürüyüşler gibi gündelik alışkanlıklar, kolektif hafızanın sürdürülmesine imkân sağlamıştır.

\section{0-1990 dönemi}

1980'lerin sonuna kadar sanayi kimliğini koruyan Bomonti Semti'nde büyük ölçekli yatırımları tetikleyen unsurlar ortaya çıkmıştır. 1/5.000 ölçekli Dolapdere-Piyale Paşa Bulvarı ve Yakın Çevresi Nazım İmar Planı'nda (1989) kullanım biçimi ve yapı yoğunluğuna yönelik alınan kararlar doğrultusunda, önceleri sanayi alanı olarak planlanan Bomonti Bira Fabrikası ve yakın çevresi, Merkezi İş Alanı içinde gösterilmiştir. Buna bağlı olarak gelişen ve binaların kullanımında meydana gelen en önemli değişimlerden biri, eskiden üretim yapılan bodrum ve giriş katlarının depo, pazarlama ve yönetim birimlerine, fabrika satış mağazalarına dönüştürülmesidir. Bir diğer ifadeyle, hâkim sanayi kolları, üretim kimliğini kaybederek iş merkezi ve tüketim karakteri kazanmaya başlamıştır.
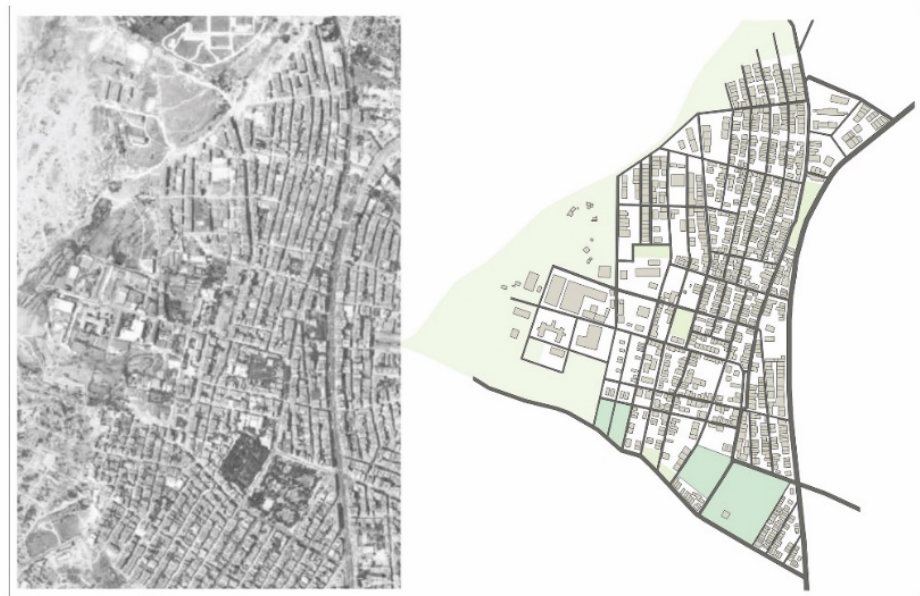

Şekil 8. 1970-1990 dönemi Bomonti Semti'nin mekânsal örüntüsü (Kaynak: İBB Şehir Haritası; Gürleyen, 2018) 
Sosyal, ekonomik ve politik dönüşümler ve planlama ideolojileri, hizmet sektörünü ön plana çlkarmış, ticaret fonksiyonunun zamanla konut dokusunun içine girmesi ile beraber bölgenin karakteristiği değişmeye başlamıştır (Tekeli, 2013). 1954 Beyoğlu Nazım İmar Planı'nda belirtilen yeşil bant önerisi, orta yoğunluklu konut alanına dönüştürülmüştür. Sosyal ilişkilerin ve kültürel değerlerin uyum içinde sürdürülmesine olanak tanıan bostanlar, bahçeler ve açık alanların korunamaması, belleğin mekânsal ve toplumsal çerçevesini kırılgan hale getirmiştir. Böylece, topluluklar tarafından icat edilen geleneklerin dayanıksız hale gelmesine neden olmuştur.

Bunların yanı sıra, Bomonti Semti, hiçbir kültürün birbirinden ayrışmayarak aynı perspektifte yaşadığı bir yer olma niteliğini sürdürmüştür (Öğüt, 2010). Kutlamalar, yerel uğraşlar, eğlenceler ve bedensel tekrarlar, kentsel kolektif belleğin içsel bileşenlerini oluşturmaktadır. Belirli aralıklarla tekrarlanan pazar buluşmalarına, pikniklere ve akşam kutlamalarına kendi payını getirme kültürü, toplumsal düzlemde kazanılan sembolik bir anlama, kültürel kodlara ve hayali hafıza topluluklarının oluşumuna karşılık gelmektedir (Lefebvre, 2012).

\section{0-2000 dönemi}

1990'ların ikinci yarısında, Halaskargazi Caddesi ekonomik, kültürel ve sosyal dinamizmini ve etkinliğini hızı bir şekilde yitirmeye başlamıştır. Halaskargazi Caddesi'nin kent yaşamına tekrar dâhil edilebilmesi için gece gündüz yaşayan, canlı ve melez bir mekânsal yapıya dönüştürülmesi hedeflenmiştir. Mevcut yaşam alışkanlıklarını ve gereksinimlerini önemsemeyen bir yaklaşımla, ticarete ve turizme yönelik kullanımlar odağa alınmıştır.

1/5.000 ölçekli Dolapdere-Piyalepaşa Bulvarı ve Yakın Çevresi Nazım İmar Planı, yapılan bazı değişiklerle birlikte 1994 yılında tekrar onaylanmışır. Merkezi iş alanı içinde kalan imalat sanayinin Bomonti Semti'nden uzaklaştırılması ve ticaret ve turizm odaklı gelişmelerin desteklenmesi yönünde kararlar alınmıştır. Bomonti Bira Fabrikası ve bazı yapı adaları (Fransız Hastanesi, Feriköy Halk Pazarı, İplik Fabrikası, MSGSU Bomonti Yerleşkesi) “Bomonti Turizm Merkezi" olarak tanımlanmıştır. Buna ek olarak, 1/50.000 ölçeğinde hazırlanan İstanbul Metropoliten Alan Alt Bölge Nazım Planı'nda (1994) Bomonti Semti "orta yoğunluklu konut alanı ve merkezi iş alanı" olarak belirtilmiştir. 
Üst ölçek planlama politikalarının etkisiyle, sanayi alanlarının desantralizasyonu meydana gelmiştir. Sanayi alanlarının yanı sıra, konut sektörü dinamiklerinde köklü bir dönüşüm yapmak amacıyla merkezi iş alanlarına rezidans işlevinin eklenmesine yönelik girişimler ortaya çıkmıştır. Bellek üreticileri tarafından tanımlanan yeni konut düzeninin içe dönük yapısı ve keskin mekânsal sınırları, sokak yaşantısına, gündelik ilişkilere, rutinlere ve ortaklaşa eylemlere ters düşmektedir. Farklı birçok kültürün bir arada yaşadığı ve semt kültürünün benimsendiği Bomonti'nin mekânsal ve sosyal açıdan yalıtılmasina neden olmaktadır.

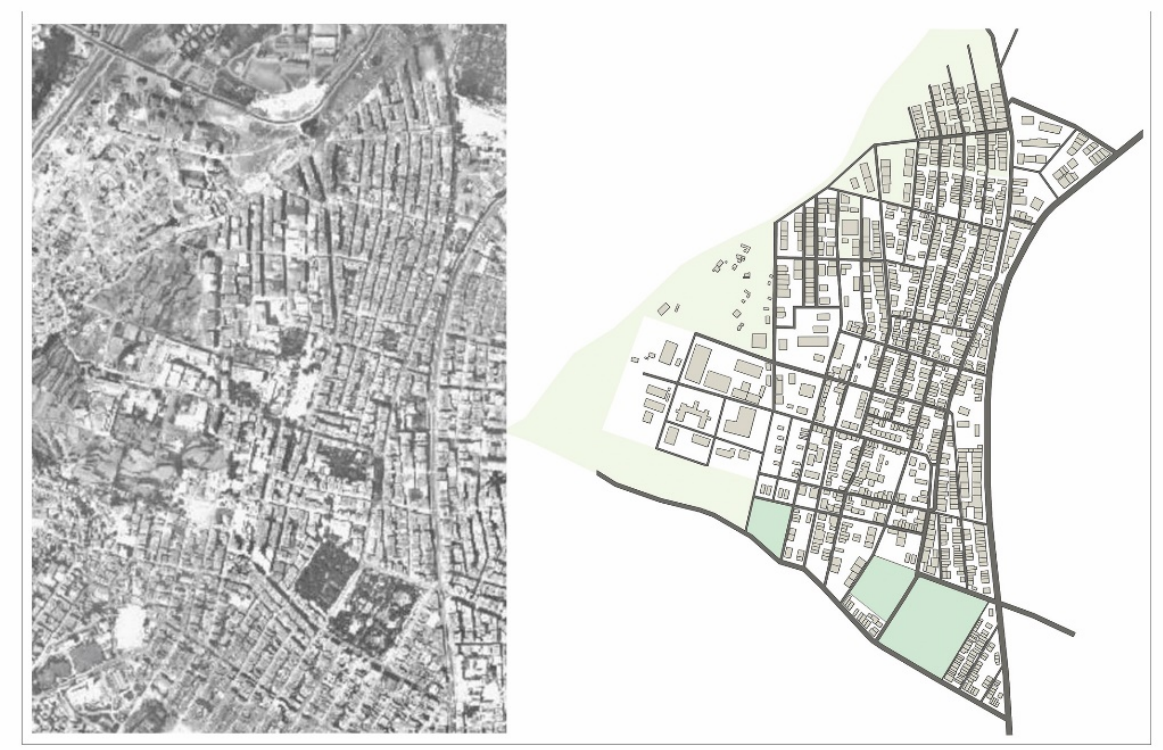

Şekil 9. 1990-2000 dönemi Bomonti Semti'nin mekânsal örüntüsü (Kaynak: İBB Şehir Haritası; Gürleyen, 2018)

\section{0-2010 dönemi}

Bomonti Bira Fabrikası ve yakın çevresinin turizm merkezi olarak ilan edilmesinin ardından, 1/5.000 ölçekli Dolapdere-Piyalepaşa Bulvarı ve Yakın Çevresi Revizyon Nazım İmar Planı'nda (2005) Bomonti Semti'nin yoğunluğunun artırılmasına ve ticari kullanımların daha fazla olmasına karar verilmiştir. 1/1.000 ölçekli Dolapdere-Piyalepaşa Bulvarı ve Yakın Çevresi Uygulama İmar Planı'na (2006) göre Bomonti Bira Fabrikası ve yakın çevresini kapsayan merkezi iş alanı için yapılaşma koşulları maksimum 3 emsal olarak belirlenmesine rağmen herhangi bir kat yüksekliği sınırlaması getirilmemesi nüfus artışını teş- 
vik etmiştir. Bomonti Semti'nin güneyinde ada biçiminde inşa edilen dikey rezidanslardan dolayı yeşil alanların ve su kanallarının izleri yok olmuştur. Kentsel gelişme dinamiklerinin yüksek binaların gölgesinde kalması, açı yeşil alanların \%23'lük orandan \%9'lara kadar azalmasına neden olmuştur.

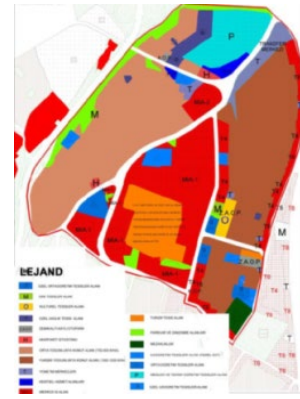

Şekil 10. 1989, 1994, 2005 Dolapdere-Piyalepaşa Nazım İmar Plan ve 2006 Uygulama İmar Planı (IBB Plan Arşivi)

2000'li yılların başlarından itibaren Tekel'in İstanbul deposu olarak kullanılan ve metruk hale gelen Tarihi Bomonti Bira Fabrikası, 2007 yılında özelleştirilmiştir. Fabrika alanındaki tescilli yapılar "tarihin yenilikle buluşma noktası", "kültür ve iş dünyasının kesişim noktası", "genç ailelerin yeni eğlencesi”, "her günün dolu dolu geçtiği kültür ve eğlence kompleksi”, “İstanbul'un görülmesi gereken çekim merkezi" başlıkları ile pazarlanmıştır. Tescilsiz binaların bulunduğu bölge, Hilton Worldwide ile işbirliği içinde 2014 yılında konaklama ve kongre merkezi olarak hizmete açılmıştır. Tekel'in özelleştirilmesinin ardından gündeme gelen yıkım ve işlev değişikleri, insanların sosyo-mekânsal gereksinimlerinin, sosyal değerlerinin ve önceliklerinin dikkate alınmadığını göstermektedir.
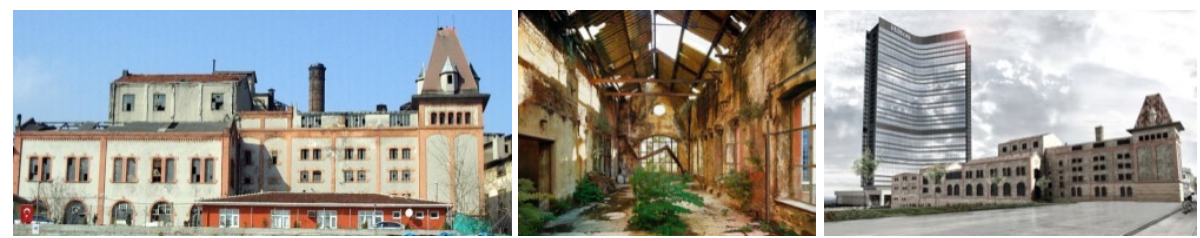

Şekil 11. Bomonti Bira Fabrikası'nda üretim faaliyetlerinin durması, fabrikanın metruk hale gelmesi ve restorasyon sonrası yenilenen yüzü (Şişli Belediyesi)

İdeolojik unutturma biçimi olarak ortaya çıkan plazalar ve rezidanslar, toplumun ortak bir anlatı etrafında örgütlenmesinin önüne geçerek toplumların ve mekânların geleceğini hatırlama eylemi üzerinden yeniden kurgulamaktadır (Auge, 2008). Hâkim ideolojinin öngördügü şekilde, unutma ve hatırlama 
pratikleri arasında yapılan seçimler toplumu (geleceği) manipüle etmektedir (Nora, 1989). Hafizadan ve geçmişten referans almadan gelişen, geçici toplumsallığı içinde barındıran büyük ölçekli yapılar, her an tüketime açık olduğundan ve kalıc hiçbir iz ve anlam taşımadığından tabula rasa konumundadır (Auge, 2008).
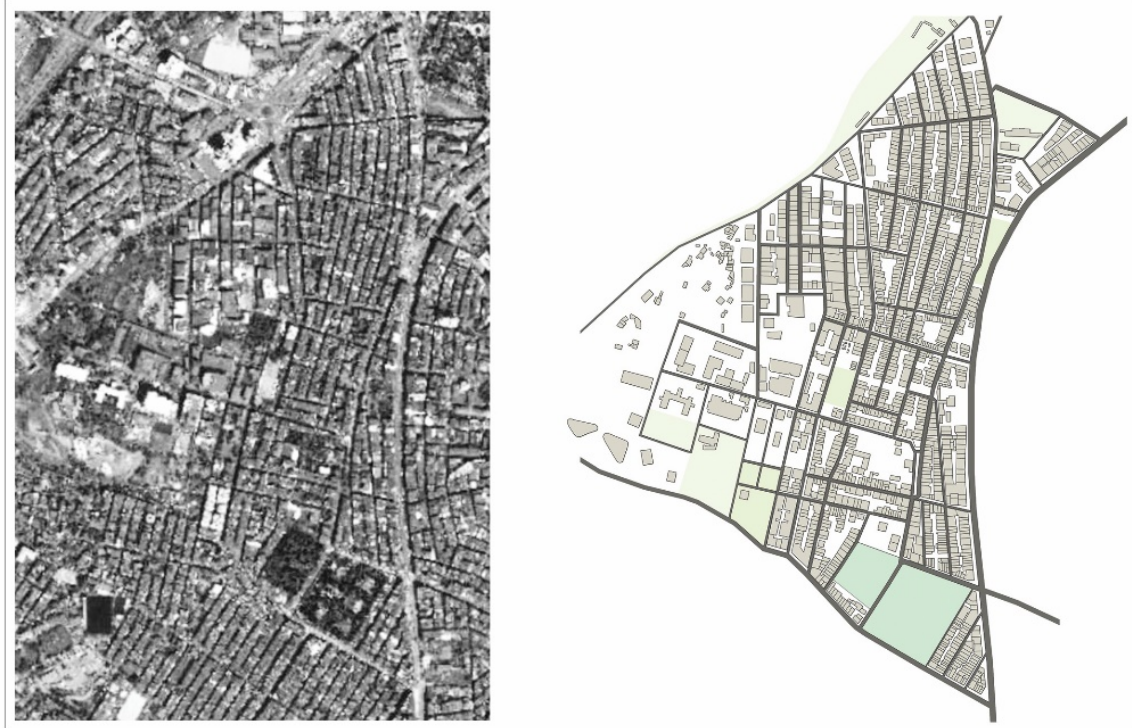

Şekil 12. 2000-2010 dönemi Bomonti Semti'nin mekânsal örüntüsü (IBB Şehir Haritası; Gürleyen, 2018)

1/100.000 ölçekli İstanbul Çevre Düzeni Planı'nda (2009) Bomonti ve yakın çevresi "Merkezi İş Alanı ve Bütünleşme Bölgesi" olarak gösterilmiştir. Plan kararlarına göre yönetim, kontrol, koordinasyon, ticaret, finans ve hizmet fonksiyonları ve bunları destekleyecek kültür endüstrileri, donatı alanları ve konaklama tesisleri, konut alanları ile bütüncül olarak ele alınmalıdır. Mevcut sanayi alanlarının ticaret ve hizmet sektörüne dönüştürülmesi ve planda belirlenen alanlara aktarılması gerekmektedir. Bunun sonucu olarak, 2009 yılında SSK Bomonti Fabrikası ve 2010 yılında Hisar İplik Fabrikası ve Kazova Tekstil Fabrikaları kapatılmıştır. İşçilerin örgütlü hareket etmelerine ve kolektif eylemlerine rağmen, sanayi kimliğini sürdüremeyen yapılar kentsel belleğin çözülmesine ve kırılganlaşmasına neden olmuştur.

\section{0-2020 dönemi}

İnşaat odaklı ekonomik büyüme yaklaşımları çerçevesinde biçimlenen planlama kararları ve küresel sermaye girişimleri, mekânsal organizasyonun, 
sosyal ilişkilerin ve kültürel örüntünün değişimine neden olmuştur. 2016 y1lında eski yerleşim örüntüsü ile aynı seviyede yatay olarak gelişen ve sokakla iç içe olan rezidanslar yerine, yan yana dizilen, ada biçiminde, dikey rezidanslar inşa edilmeye başlamıştır. Kendi yaşam alanlarını belirleyen büyük ölçekli yapı adaları ve yalıtılmış sosyal ilişkiler, toplulukların ortak hafızasına ait olan simgesel ögelerin anlamlı düzenini kesintiye uğratmaktadır (Boyer, 1996).
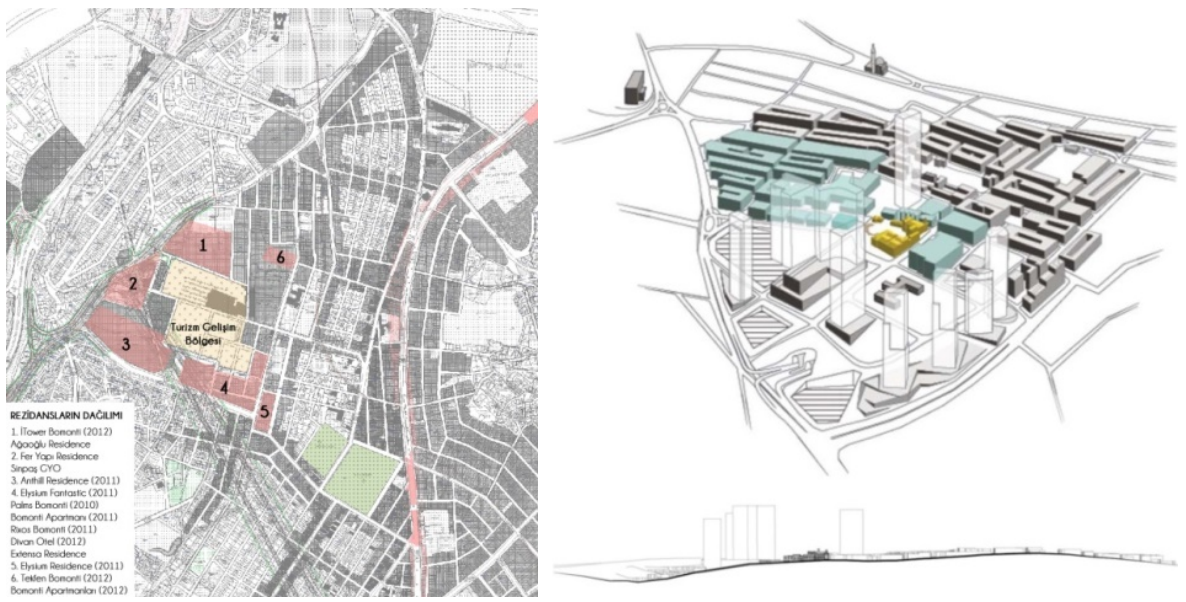

Şekil 13. 2018 Uygulama İmar Planı üzerinden rezidansların dağılımı ve Bomonti Bira Fabrikası yakın çevresinin yeni çehresi (Şişli Belediyesi; SANALarch)

Gökdelenlerin simgelediği gelecek öngörüsü, gündelik hayatın insan ölçeğini aşmakta, yüz yüze ilişkilere dayanan, aidiyetlik hissi veren, alışıldık mahalle yaşantısına, yeni ve farklı bir bakış getirmektedir. Sınırları belirsizleştiren, yerel ve özgün olanı görünmez kılan bir anlayışa dönüştürmektedir. Yüksek katlı kompleks binalar, modernleşmenin etkisiyle daha görünür hale gelmiştir. Mekânlar kütük benzeri, her yerde aynı olan, tüm çevrelerde eşit göze çarpan, modüler cam kutulara dönüşmüştür (Berman, 2004).

Kurutulan dere ve ortasından geçen İncirli Dede Caddesi, Teneke Mahallesi ile Rezidans Adaları arasında görünmez bir sınır oluşturmaktadır. Bomonti Semti bir yandan yerleşik gündelik yaşam pratiklerinin sürdürülmesine imkân sağlarken, diğer taraftan yatayda ve dikeyde büyüyen yapılarla farklı gündelik yaşam pratiklerinin inşa edilmesine sahne olmaktadır (Kovanlıkaya, 2017). Gözün sınırlarını zorlayan yüksek binalar, hafızasız bir ortam yaratmakta (De Certeau, 1984) ve böylece geçmişin tutma kapasitesi kaybolmaktadır (Jameson, 1994). 


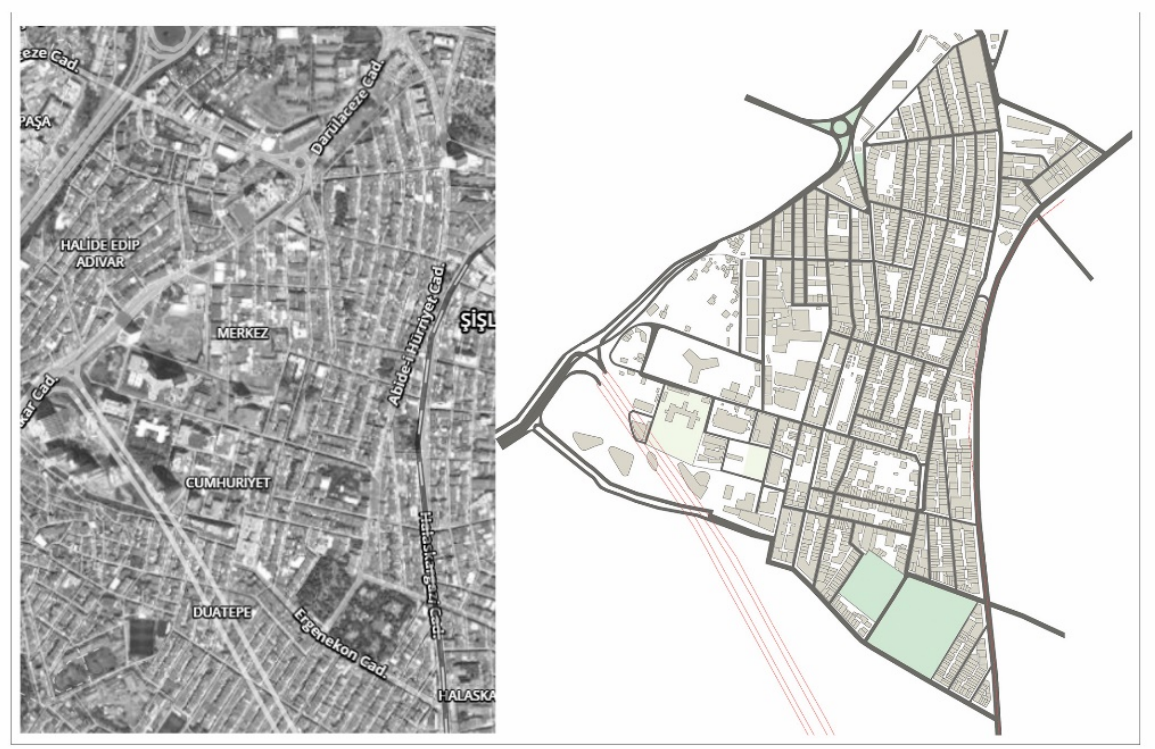

Şekil 14. 2000-2010 dönemi Bomonti Semti'nin mekânsal örüntüsü

(Kaynak: İBB Şehir Haritası; Gürleyen, 2018)

2014 yllında "Bomontiada" olarak yeni işlevini kazanan Tarihi Bomonti Bira Fabrikası, farklı kullanıcıları bir araya getiren, konser, performans ve sergi alanlarını buluşturan, düşünmeyi, üretmeyi ve eğlenmeyi birbirine bağlı aktiviteler olarak destekleyen "yaratıc bir kültür kampüsü” olarak kurgulanmıştır. Boş zaman aktivitelerinin önemli bir parçasını oluşturan atölyeler ve kafeler, sosyal ilişkilerin ve kültürel birikimlerin aktarıldığı toplanma, vakit geçirme ve öğrenme mekânları olarak ön plana çıkmıştır. Bomonti'nin kent bahçeciliği ve bostan kültürünü devam ettirmek amaciyla ekim biçim faaliyetleri düzenlenmiş ve farkındalık yaratılmaya çalışılmıştır. Semtin mekânsal pratiklerinin değişmesine bağlı olarak belleğin yeniden üretimi, mekânın algılanan ve yaşanan toplumsallığını değişime uğratmıştır. Burada söz konusu olan belleğin canlı tutulmasından ziyade bugüne ait olanın yeniden inşası ve belleğin gündelik biriktirmeler sonucunda kendi tarihini yaratmasıdır. Zaman ve anlam kaymasına uğrayan bellek, yeniden kurucu nostaljiye dönüşmüştür (Boym, 2009).

2019 yılında Kültür Varlıklarını Koruma Bölge Kurulu tarafından Diyanet İşleri Başkanlığına devredilen Bomonti Bira Fabrikası'nın “dini kültür merkezine" dönüşmesine karar verilmiştir. Sergi ve toplantı salonu, kütüphane, öğrenci yurdu, mescit ve yeraltı otoparkından oluşan dini bir kompleks planlanmaktadır. 1890 yılında kurulan Bomonti Bira Fabrikası ve ona ait binaları, 1998 yılında İstanbul 1 No'lu Koruma Kurulu tarafından korunması gereken kültür 
varlığı statüsüne alınarak tescil edilmesine rağmen geçtiğimiz günlerde yıkım çalışmaları başlatılarak kentin kolektif belleği bağlamından koparılmıştır. Bomontiada'nun bulunduğu Birahane Sokak üzerinde yer alan ve 5 yıldır Feriköy Bomonti Mescidi olarak faaliyet gösteren yapının seçici bir tavırla ön plana çkarılması, belleğin manipüle edilmesini kolaylaştırmaktadır.

Kentsel mekânsal dönüşümlerin ve bazı sosyal grupların yer değiştirmesi sonucunda, öğrenciler, gençler, beyaz yakalılar ve burjuvazi kesim mahalle yaşantısına eklemlenmiştir. Bu durum, farklı gündelik pratiklerin gereksinmesine bağlı olarak geleneklerin yeniden icat edilmesine neden olmuştur. Nüfus değişimlerinin belirli aralıklarla yaşandığı bir yerde, toplumun kök salmanın tersine taşınabilir köklere sahip olmasının getirdiği kırılganlık durumu, kentsel belleğin manipüle edilmesine açık hale getirmiştir.

Rezidansların çatısında konumlanan küçük bahçeler, "komşuluk ilişkilerinde yenilikçiliğin öncüsü" (Bomonti Apartmanları), "yeşil sokaklarla çevrili sakin bir yaşam" (Tekfen Bomonti), "yeşil ortamlarda akıllı binalar" (Anthill Rezidans) ve "yeşilliklerle dolu teraslı binalar" (Elysium Rezidans) söylemleri ile pazarlanmaktadır. Küçük ölçekli, yapay yeşil alanlar, özel ve kamusal alan arasındaki çatışmayı ortaya koymaktadır. Gözenekli mekânların yitirilmesine ve endüstriyel, çevresel ve bilişsel geçmişi kodlayan sembolik öğelerin izlerinin silinmesine neden olmaktadır. 

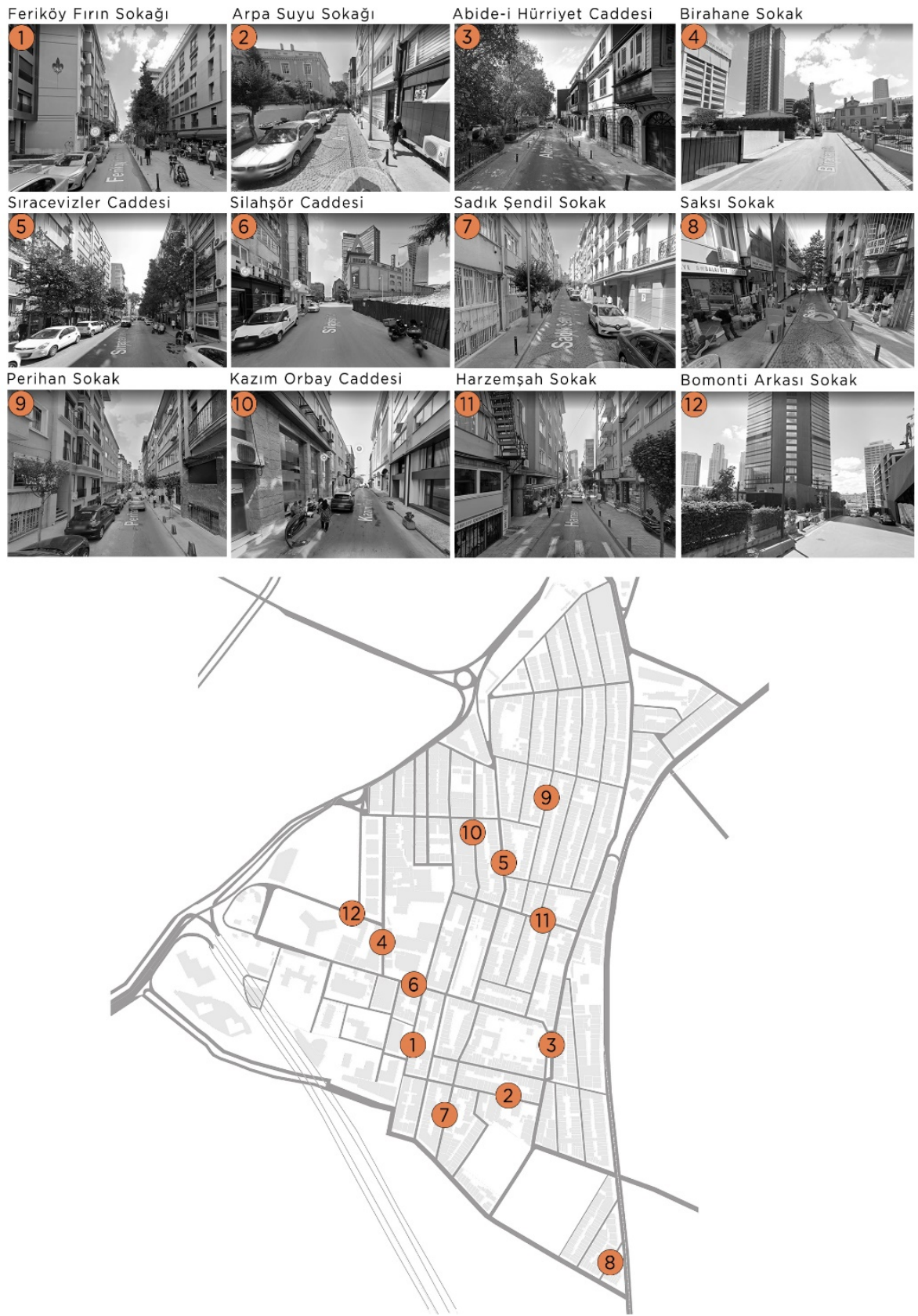

Şekil 15. Bomonti Semti Sokakları (Google Haritalar Sokak Görünümü, 2020) 
Kentsel mekânın pazarlanması sürecinde bellek üreticileri tarafindan yeşil alan vurgusunun yapılması, mevcut yeşil alanların yok edildiği gerçeğini değiştirmemektedir. Tekfen Rezidansının Gürcü Katolik Kilisesi'nin eski bahçesinde konumlanması, Bomonti Bira Fabrikası'nın olduğu açık alana Hilton Oteli'nin inşa edilmesi, Bomonti Bira Bahçesi'nin parseline MSGSU Binası'nun yapılması, eski Nestle Fabrikası'nın bahçesinde imara açlan Elysium Rezidansı ve diğer rezidans projelerinin (Bomonti Apartmanları, Extensa, Palms, Anthill, Ağaoğlu, Sinpaş ve Rixos) yapım sürecinde birçok ağacın kesilmesi buna örnek gösterilebilir. Yeşil alanların izlerinin silinmesinin yanı sıra, büyük ölçekli yapılar tarafından engellenen pasif havalandırma, hâkim rüzgâr yönünün değiştirilmesi, temiz hava akımının engellenmesi, havanın toprakla buluşamaması bölgede isı adalarının oluşmasına yol açmaktadır. Dolayısıyla, Bomonti'de süregelen kentsel gelişim dinamikleri, yüksek binaların gölgesinde bol güneş 1şığı almayanlar için piyasa güçleri tarafından yaratılan yeni kentsel ütopyaların bir girişimidir (Özberk, 2013).

Diğer taraftan, kolektif belleğin oluşumunda etkili olan kutsal yerler ve ortaklaşa öğrenme alanları (Saint Michelle Fransız Lisesi, Ermeni Illkokulu, Rum Illkokulu, Otistik çocuklar için eğitim veren özel Tohum Vakfı Okulu, Bulgar, Gürcü, Fransız, Rum ve Ermeni kiliseleri ve Şişli Cami) birlikte yaşama kültürünün benimsenmesine ve zengin kültürel birikimlerin korunmasına yardımcı olmaktadır. Mahallenin gündelik pratiklerinde gerçekleşmeye devam eden törenler, ayinler ve kutlamalar kolektif hareket etme duygusunu harekete geçirmekte, toplumsal bağları kuvvetlendirmektedir. Gündelik çalışma zorunluluklarının bastırdığı bütün arzuları serbest bırakmaktadır (Lefebvre, 2012). Bedensel ve ruhsal zevklerin farklı bağlamlarda ortaya çıkışı, öngörülen zamanda gerçekleşen tekrarların sınılarını aşmakta, anlık ve kendiliğinden gerçekleşen kolektif eylemlere dönüşmektedir. Gündelik yaşamın kendi ritminde ve döngüsünde anlamlı ve sembolik birikimlere imkân sağlamaktadır. Toplumsal olarak inşa edilmiş gelenekler, bedensel eylemler ve ritüeller (Durkheim, 2013) kolektif belleğin içsel dinamiklerini kentsel sisteme bağlamaktadır. 
Tablo 4. Bomonti'nin tarihsel katmanları üzerinden belleğin başkalaşım süreci (Kişisel Çalışma)

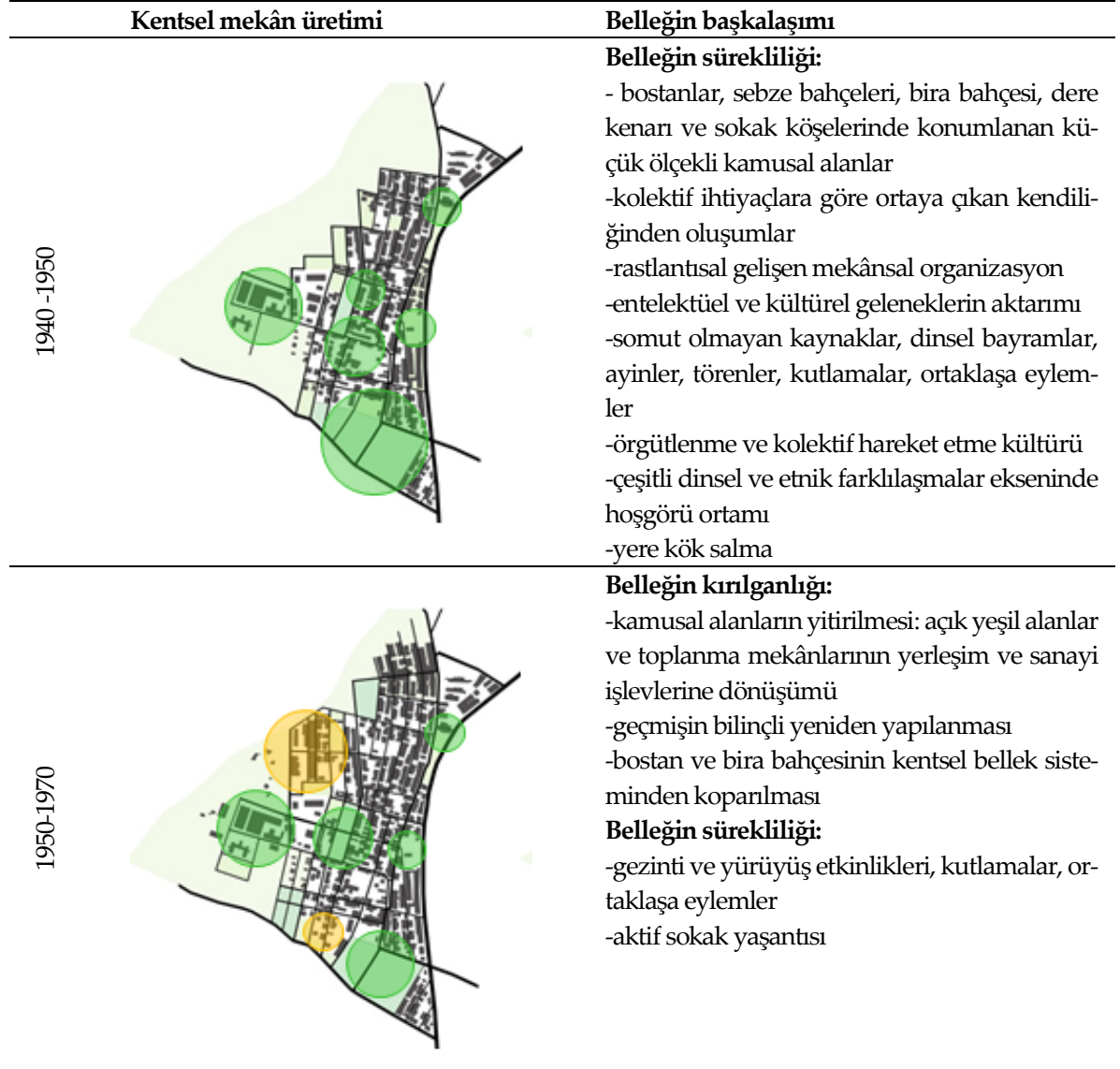

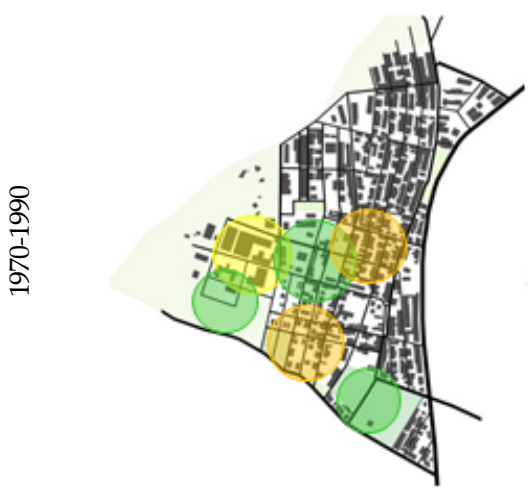

\section{Belleğin kırılganlığı:}

-sanayi kimliğinin merkezi iş alanı ve tüketim karakterine dönüşmesi

-ticaret fonksiyonunun zamanla konut dokusunun içine girmesiyle sokak örüntüsünün değişmesi

\section{Belleğin yeniden üretilmesi:}

-gündelik yaşamın yeniden inşası

-bireylerin tüketici kimliklere bürünmesi

Belleğin sürekliliğ̈i:

-kendi payını getirme külttürü

- kutsal yerler, sokaklar, açı alanlar ve üretim faaliyetleri

-sembolik anlam, kültürel kodlar, kutlamalar, yerel uğraşlar, eğlenceler ve bedensel tekrarlar 


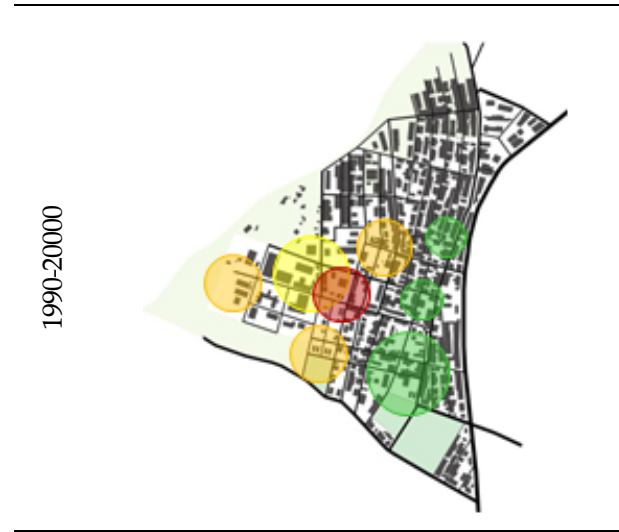

\section{Belleğin kırılganlığı:}

-sanayinin desantralizasyonu, ticaret ve turizm odakl gelişmeler

\section{Belleğin manipülasyonu:}

-kentsel mekânın pazarlanması ve metalaştırılmasi

-insanların tüketim nesnesi olarak bir araya getirilmesi

Belleğin yeniden üretilmesi:

-gündelik yaşam etkinliklerinin yeniden inşası -çoklu gündelik karşlaşmaların ve ortaklaşa eylemlerin azalması

-alışkanlıkların ve iletişim kurma biçimlerinin değişmesi

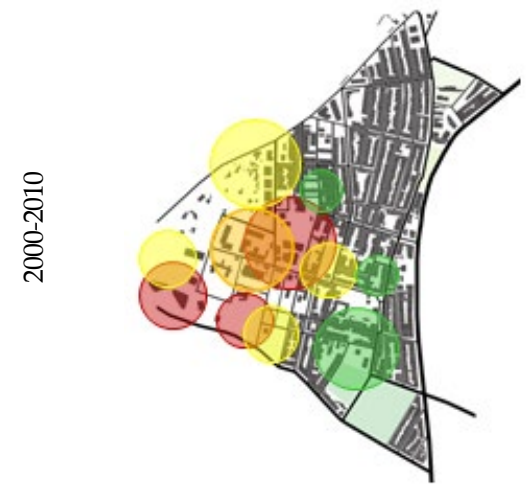

\section{Belleğin kırılganlığı:}

-ticari ve turizm karakterinden kültür ve eğlence kimliğine bürünmesi

-sanayi kimliğini sürdüremeyen yapılar, üretim kimliğinin kaybolması

-açk kamusal alanların azalması

-yeşil alanların ve su kanallarının izlerinin silin-

mesi

\section{Belleğin manipülasyonu:}

-ideolojik unutturma biçimi olarak ortaya çkan plazalar ve rezidanslar -kentsel mekânın tektipleşmesi

Belleğin yeniden üretilmesi:

-sosyal grupların yer değiştirmesi

-yeni ilişki biçimleri ve alışkanlıklar

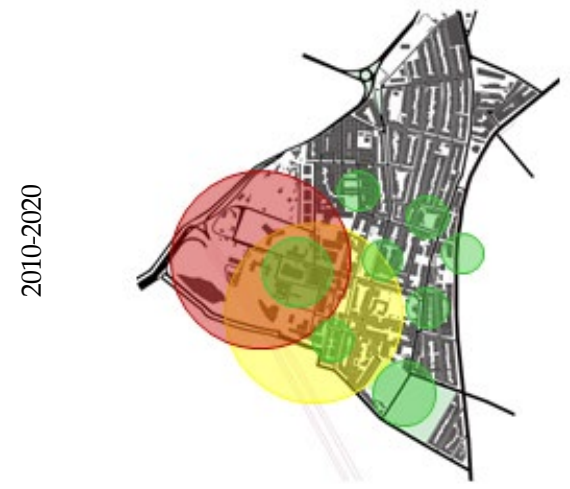

Belleğin manipülasyonu:

-kentsel mekânın melezleşmesi

-gündelik yaşamın eğlence ve kurucu tarihle özdeşleştirilmesi

-belirli temalar çerçevesinde kopyalanan ve yeniden inşa edilen melez mekânsal oluşumlar

Belleğin yeniden üretilmesi:

-mekânsal organizasyonun, sosyal ilişkilerin ve kültürel örüntünün değişimi

- kendi yaşam alanlarını belirleyen ve ada biçiminde inşa edilen büyük ölçekli yapıların etkisiyle sosyal ilişkilerin yalıtılması

-kök salmanın tersine taşınabilir köklere sahip olma

belleğin manipülasyonu belleğin kırılganlığı

belleğin yeniden üretimi $\bigcirc$ belleğin sürekliliği

\begin{tabular}{|c|c|c|c|c|}
\hline & $\% 48$ & $\% 23$ & $\% 9$ & $\% 1$ \\
\hline 1940 & 1970 & 1990 & 2010 & 2020 \\
\hline
\end{tabular}




\section{Sonuç ve Değerlendirme}

Kentsel dönüşümün ranta dayalı işlevsel bir araç haline gelmesinin ardından spekülasyonlardan daha fazla faydalanmak amaciyla rekabete giren özel sektör, kent merkezlerine yakın konumda olan bölgeleri kazanç sağlama aracı olarak görmektedir. Bomonti Semti, mevcut yapı stoklarının maksimum kar amacı ile yıkılıp yeniden yapılandırılması ve yoğun yaşam alanlarına dönüştürülmesi sürecinden kaçınılmaz bir şekilde etkilenmiştir. 2000'lerin başından itibaren küreselleşme ve neoliberal kentleşme politikalarının etkisi altında önemli bir yatırım nesnesi haline gelmiştir. Tüketim kültürünün belirleyiciliğinde geçmişin manevi yerleşimlerinin yerine geçen yeni mekânsal kurgunun odağında yer almıştır.

Küreselleşme eğilimlerine paralel olarak gelişen seri üretim ve kitlesel tüketime dayalı mekân üretimi, kentsel bellek krizinin başlıca nedenlerinden biridir (Castells, 1993). Yatırım ve turizm odağına yerleşen Bomonti Semti'nde tüketimin bir kimlik göstergesi olarak kullanılması, kentsel dokunun ve mülkiyet yapılarının radikal değişimler geçirmesine neden olmuştur. Bomonti'nin üretim kimliğinin ve endüstri izlerinin geri dönüşü olmayacak biçimde tabula rasa olarak ortadan kaldırılması ve Bomonti'nin vitrine dönüşen mekânları, kentsel yeniden yapılanma projelerine ivme kazandırmıştır. Yalnızca turistin gözünden bakılarak belirlenen ihtiyaçlar ve beklentilere cevap verecek biçimde dönüştürülen kentsel mekânlar (Urry, 1990) yer duygusunu, aşinalık hissini, mekânsal istikrarı ve hafıza izlerini aşındırmaktadır. Entelektüel ve kültürel geleneklerin, gündelik yaşam biçimlerinin pazarlanmasına ve metalaştırılmasına sebep olmaktadır.

Kentsel stratejilerin yerinden ve bağlamindan kopuk olması, kentsel mekânın ürünlere dönüşmesine, gündelik yaşamın eğlence ve kurucu tarihle özdeşleştirilmesine ve bir başka yaşam biçimi olarak ele alınmasına yol açmıştır. Sanat etkinliklerinin ve eğlence faaliyetlerinin yanı sıra lüks konut sitelerine alışveriş unsuru katma eğilimi, insanları tüketime doğru yönlendirmektedir. Bomonti Semti kullanıcıları, ihtiyaçları karşılayan bireyler ve tüketici kimlikler olarak sermayenin odağında yer almaktadır. Bu durum, kültürel birikimlerin ve gündelik yaşam pratiklerinin yeniden inşasına neden olmuştur. Gündelik yaşamın yönlendirilmesi ve parçalara ayrılarak denetlenmesi, tüketici haline getirilen bireyler ve düşüncelerin tüketilmesi aracilığı ile mümkün olmaktadır (Lefebvre, 1993).

Bomonti Semti'nde deneyimlenen gündelik yaşam, akışkan olma özelliğini kaybetmeye başlamıştır. Kentsel mekânın yerelliğe, alışkanlıklara, anlama ve 
aidiyete yönelik vurgusu azalmaya başlamıştır. Kolektif düşünme, üretme, etkileşme, karşılaşma, birlikte yürüme gibi ortaklaşa gerçekleşen gündelik yaşam faaliyetleri üzerinden belirlenen kullanım taktikleri ve ilişkiler sistemi, kentsel bellek sistemine tutunmaya çalışırken; mahallenin içerisine sızan yeni oluşumlar, belleğin manipüle edilmesine neden olmaktadır. Farklı bağlamlardan koparılmış ve yorumlanmış temsili çerçeveler, yeni bir bellek inşa etmektedir. Birbirlerinin içinde eriyen mekânsal temsiller, özgün içerik ve kökenlerini yitirmeye başlamıştır.

Öte yandan kentsel kolektif belleğin kırılganlaşması, kesintilere ve kopmalara uğraması, manipülasyonu ve yeniden üretimine rağmen belleğin sürekliliği yaşanmaya devam etmektedir. Bomonti Semti, mesafeleri daraltan, etnik kökenleri birbiriyle kaynaştıran, mekânla insana ve insanla manzaraya uyum gösteren bir yer olma özelliğini sürdürmektedir. Toplumsal işleyişin ortak kavramsal çerçevesini oluşturan kültürel birikimler, değerler ve paylaşımlar, gündelik yaşamda tekrarlanma ve kalıcılık gösterme eğilimlerini korumaktadır. 


\section{Extended Abstract}

\section{Metamorphosis of Memory in the Production of Urban Space: The Example of Bomonti}

\author{
Tuğçe Gürleyen \\ ORCID: 0000-0001-6091-8524
}

\author{
Mehmet Ocakçı \\ ORCID: 0000-0002-2987-1680
}

The rapid production of postmodern space produced under the leadership of large-scale urban transformation projects not only witnesses to the homogenisation and standardization but also to the hybridization of the Bomonti Neighbourhood. In this process, where local culture and collective memory are ignored, blurred and begin to be manipulated; traditions and patterns of behaviour are reinvented by becoming similar. Abandoned buildings and industrial warehouses converted into art galleries, expensive shops, cafes, hotels, residential and office spaces are an example of hybrid spaces where copies of historical sites are built or developed based on specific themes. These areas, which stand out as places of circulation, consumption and communication and differ from traditional ones, turn into placeless formations where short-lived, instant images and impermanence are experienced. Therefore, the metamorphosis of memory experienced in Bomonti is the outcome of the hybridization as well as the multi-dimensional and complex spatial transformations.

This study aims to explore socially constructed habits of life with the collaboration of urban experiences from past to present in the context of space and shared memory. It tries to understand the social production of space with the memory traces of the past and the present. It emphasizes the importance of transferring the plural practices of different lifetimes and the organizational forms of collective memory to the planning and design process. Within the scope of the study, the visual ethnography method, which is a quantitative and qualitative research method, was used. The urban memory reading through historical layers is based on ancient maps, engravings, photographs, drawings, postcards and texts found in personal or official archives. Spatial and social 
traces that are fragile or interrupted, manipulated, reproduced and continual are evaluated comparatively within the framework of memory theories.

In the period from 1940 to 1950, Bomonti Neighbourhood provides the opportunity for spontaneous formations that emerged according to collective needs. Intangible resources, religious holidays, rituals, ceremonies, celebrations and collective actions, as well as the collective and incidental spatial organization, constitute the nodal points of the urban memory. It is seen that an atmosphere of tolerance is experienced in the axis of various religious and ethnic differences, and a culture of organization and collective action is adopted. Thus, the transmission of intellectual and cultural traditions rooted in the place is made possible. The orchards, vegetable gardens, Beer Garden, small pocket purses located on the edge of the stream and street corners have helped to ensure the continuity of the green area.

The transformation of open green spaces and gathering spaces into residential and industrial functions in the period from 1950to 1970 refers to the interrupted relations and spaces in the urban context. The fragility of the collective memory is sharpened as a result of the erasure of the gardens and the Beer Garden from the urban context. Conscious structuring of the past caused the loss of public spaces. On the other hand, active street life, journey and walking activities, celebrations and collective actions point to the continuity of memory.

In the period from 1970 to 1990, the transformation of the industrial identity into the central business field and consumption character, the change in the street pattern as the commercial function entered the housing fabric in time caused the fragility of the memory. The reconstruction of daily life and individuals' assuming consumer identities corresponds to the reproduction of memory. Sacred places, streets, open spaces and production activities stand out as nodal points of urban memory. Despite the high level of fragility of memory, symbolic meaning, cultural codes, celebrations, local occupations, entertainment and bodily repetitions that ensure the continuity of memory constitute the internal components of the urban memory system.

While the decentralization of industry, trade and tourism-oriented developments in the period from 1990 to 2000 caused the fragility of memory, the marketing and commodification of urban space, bringing people together as consumption objects lead to the manipulation of memory. Erasure of the garden and production culture from the urban memory system causes the collectivism to dissolve. Considering the relationship between public spaces and settlement pattern, it is seen that multiple daily encounters have decreased. Collective actions that are taken place in the economic and social practices of everyday life 
and are embedded in traditions, have begun to unravel and reconstructed. The constant change of urban topography transformed habits and communication styles, as well as neutralizing the local order, cultural accumulations, urban experiences and spatial organization dynamics (De Certeau, 1984).

In the period from 2000 to 2010, the loss of production identity of the Bomonti Neighbourhood caused the fragility of the memory. The traces of green areas and water channels are erased from urban memory systems. Plazas and residences, which emerged as a form of ideological forgetting as a result of the manipulation of memory, point to the homogenisation of the urban space. With significant changes in the socio-demographic structure, the new daily relationship forms, habits and values that emerge due to the displacement of social groups correspond to the reproduction of memory.

In the period from 2010 to 2020, the identification of everyday life with entertainment and history led to a change in spatial organization, social relations and cultural pattern. Abandoned industrial buildings have turned into hybrid spatial formations (art galleries, boutique shops, cafes, hotels and office spaces) that have been copied and reconstructed within the framework of certain themes. Large-scale buildings that define their own living spaces and were built in the form of an island caused the isolation of their social relations.

On the other hand, despite the fragility, rupture, manipulation and reproduction of the urban collective memory, the continuity of memory continues to be experienced. Bomonti Neighbourhood continues to be a place that decreases the social distances, coheres ethnic origins, and adapts to the people with the space and the landscape with the people. Cultural accumulations, values and shares preserve their tendency to show repetition and permanence in daily life.

\section{Kaynakça/References}

Amin, A.,ve Thrift, N. (2002). Cities: Reimagining the urban. Polity Press.

Assmann, A. (2011). Cultural memory and western civilization: Functions, media, archives. Cambridge University Press.

Auge, M. (2008). Non-places: An introduction to supermodernity. London and New York: Verso.

Berman, M. (2014). Katı olan her şey buharlaşıyor. İstanbul: İletişim Yayıncllk.

Blomberg, J. (1993). Participatory Design: Principles and Practices. Ethnographic field methods and their relation to design. içinde CRC Press.

Boym, S. (2009). Nostaljinin geleceği. İstanbul: Metis Yayınları.

Boyer, M. C. (1996). The city of collective memory: Its historical imagery and architectural entertainments. MIT Press: Cambridge. 
Burke, P. (2004). History as social memory. The Collective Memory Reader, New York: Oxford University Press.

Castells, M. (1993). The informational economy and the new international division of labor. The new global economy in the information age. Macmillan Education UK.

Connerton, P. (2009). How modernity forgets. Cambridge University Press.

Crane, S. A. (1997). Writing the individual back into collective memory. The American Historical Review, 102 (5).

Crinson, M. (2005). Urban memory: History and amnesia in the modern city. London: Routledge.

De Certeau, M. (1984). The practice of everyday life. University of California Press, Berkeley.

Durkheim, E. (2013). The rules of sociological method: and selected texts on sociology and its method. Palgrave Macmillan.

Gürleyen, T. (2018). Unutkanlı coğrafyasında bellek yörüngelerinin mekânsal anlatıst: Bomonti'nin gündelik hayatına etnografik bakış. Yüksek Lisans Tezi, İstanbul Teknik Üniversitesi.

Halbwachs, M. (1980). The collective memory. New York: Harper \& Row.

Halbwachs, M. (1992). The social frameworks of memory. London: The University of Chicago Press.

Hobsbawm, E., \& Ranger, T. (2012). The invention of tradition. Cambridge University Press. Hutton, P. H. (1993). History as an art of memory. Hanover, University of Vermont.

Jameson, F. (1994). Postmodemizm. İstanbul: Yapı Kredi Yayınları.

Kansteiner, W. (2002). Finding meaning in memory: A methodological critique of collective memory studies. History and Theory, 41(2).

Kovanlıkaya, Ç. (2017). Kentsel dönüşüm ile apartmanlardan rezidanslara bomonti'de yeni yaşam. Current Debates in Sociology and Anthropology, 10, London.

Lefebvre, H. (1993). The production of space. Blackwell: Oxford.

Lefebvre, H. (2012). Gündelik hayatın eleştirisi I. İstanbul: Sel Yayınları.

Lewicka, M. (2008). Place attachment, place identity, and place memory: restoring the forgotten city past. Journal of Environmental Psychology, 28(3).

Misztal, B. A. (2003). Theories of social remembering. Berkshire: Mcgraw-Hill Education.

Nora, P. (1989). Between memory and history: Les lieux de mémoire. M. Roudebush.

O'Reilly, K. (2009). Visual ethnography. Key concepts in ethnography.

Ögüt, H. (2010). Bomonti'den Harbiye'ye. İstanbul: Heymola.

Özberk, N. (2013) Piyasa eliyle üretilen kentsel ütopyalar: özel konut şirketlerinin kentsel mekân sunumu.

Postalcy, E., Kuruç Ada, A., ve Özbek Eren, Y. (2006). The new urban memory, The 42nd international society of city and regional planners congress.

Ricoeur, P. (2004). Memory, history, forgetting. University of Chicago Press, London.

Tekeli, İ. (2013). Isstanbul'un planlamasının ve gelişmesinin öyküsü. Tarih Vakfi Yurt Yayınları.

Stone, G. (2013). Visual ethnography for community participation in urban development. Uppsala University.

Till, K. E. (2005). The new Berlin: Memory, politics, place. U of Minnesota Press. 
Tümertekin, E. (1967). İstanbul'da bir sanayi bölgesi: Bomonti bir coğrafya çalışması. Baha Matbaası: İstanbul.

Tümertekin, E. (1972). İstanbul sanayiinde kuruluş yeri. İstanbul: Edebiyat Fakültesi Matbaasi.

Wertsch, J. V. (2002). Voices of collective remembering. Cambridge University Press.

Weber, M. (2009). The theory of social and economic organization. Simon and Schuster.

Winter, J. (1999). Remembrance and redemption: A social interpretation of war memorials. Harvard Design Magazine, 9.

Zat, V. (1994). Bomonti Bira Fabrikası. Dünden bugüne İstanbul Ansiklopedisi içinde Kültür Bakanlığı-Tarih Vakfı, C. 2, İstanbul.

Zhu, R. (2004). City and memory: Continuity and development of urban history in psychological dimension. South Architecture, 4. 